\title{
Crucial times for Spanish physical oceanography
}

\author{
JOSEP L. PELEGRÍ ${ }^{1,2}$, ENRIQUE ÁLVAREZ-FANJUL ${ }^{3}$, MANUEL ESPINO ${ }^{2,4}$, \\ JORDI FONT ${ }^{1,2}$, GREGORIO PARRILLA $^{5}$ and AGUSTÍN SÁNCHEZ-ARCILLA ${ }^{2,4}$ \\ ${ }^{1}$ Departament d'Oceanografia Física, Institut de Ciències del Mar, CSIC, Passeig Marítim de la Barceloneta 37-49, \\ 08003 Barcelona, Spain. \\ 2 l'Observatori Català de l'Oceà, l'OCEÀ, www.locea.org \\ ${ }^{3}$ Puertos del Estado, Avenida Partenón 10, 28042 Madrid, Spain. \\ ${ }^{4}$ Laboratori d'Enginyeria Marítima, Universitat Politècnica de Catalunya, Carrer Jordi Girona 1-3, \\ 08034 Barcelona, Spain. \\ ${ }^{5}$ Instituto Español de Oceanografía, Calle Corazón de María 8, 28002 Madrid, Spain.
}

\begin{abstract}
SUMMARY: The field of physical oceanography has undergone exponential growth in Spain during the last few decades. From a handful of self-taught researchers in the late 1960s there are now several hundred physical oceanographers distributed in some 20 Spanish institutions, and many more working overseas. The First Spanish Physical Oceanography Meeting (EOF1), held in Barcelona in October 2010, was a good example of the high quality and large variety of this research. The facilities and human resources are excellent but the alarming decrease in public investment in science due to the economic crisis must lead the Spanish physical oceanography community to define its current priorities. In this introductory paper to EOF1 we revise our history and where we are now, and suggest that progress in the near future will rely on our intelligence to sustain and enhance human capital, partnership and society-oriented research.
\end{abstract}

Keywords: physical oceanography, Spain, history, human capital, partnership, society-oriented research.

RESUMEN: TIEMPOS DE CAMBIO PARA LA OCEANOGRAFíA FÍSICA ESPAÑOLA. - El campo de la oceanografía física ha experimentado un crecimiento exponencial en España durante las últimas décadas. Desde unos pocos oceanógrafos autodidactas a finales de la década de 1960 hemos llegado a varios centenares de oceanógrafos distribuidos en unas 20 instituciones españolas, con otros muchos más trabajando fuera de España. El Primer Encuentro de la Oceanografía Física Española (EOF1), que tuvo lugar en Octubre de 2010 en Barcelona, fue un buen ejemplo de la alta calidad y amplia variedad de estas investigaciones. Las infraestructuras y potencial humano son excelentes pero nos enfrentamos ahora, como resultado de la crisis económica que estamos experimentando, con la amenaza real de una significativa disminución de la inversión pública en Ciencias que debe llevar a la comunidad de oceanógrafos físicos españoles a definir prioridades. En este artículo introductorio a EOF1 revisamos cual ha sido nuestra trayectoria y donde nos hallamos ahora, y proponemos que el progreso en un futuro cercano depende de nuestra habilidad para apoyar y fomentar el capital humano, el asociacionismo y una investigación orientada hacia la sociedad.

Palabras clave: oceanografía física, España, historia, capital humano, asociacionismo, investigar para la sociedad.

\section{INTRODUCTION}

When did we get started, where are we and how should we proceed? These are questions that we ask ourselves in the middle of any endeavour, and the development of physical oceanography in Spain is no exception. The First Meeting of the Spanish Physical Oceanography Community (Primer Encuentro de la Oceanografia Física Española, EOF1), held in Barcelona from 13 to 15 October 2010, was a good opportunity to appreciate the rapid recent progress of this field in Spain. Some of the members of the Spanish physical oceanography community had met before in larger national or international symposia, but this was the first time that we had had the chance to hold a nationwide meeting solely for this community. The response was excellent, with 138 communications on all major topics of physical oceanography presented by oceanographers from all the Spanish institutions working in this field. 
EOF1 was a time for congratulations on where we are and on the significant Spanish advancements in physical oceanography during a short period of time. However, there was little opportunity to consider where we come from and how to proceed in the future. In this essay we address these crucial questions for the future of Spanish physical oceanography: What are the main events that led to a rapid growth of this discipline? What are the future goals for the Spanish oceanographic community? What are the best ways to attain them? The last two questions are particularly important in view of the current economic situation faced by Spain, which raises doubts on the feasibility of maintaining scientific growth. It is perhaps time to rethink our priorities and to redefine the paths to be taken by Spanish physical oceanography in the next decade. We hope that this paper may help us in this task, which is to be discussed at the Second Spanish Physical Oceanography Meeting (EOF2) to be held in Madrid from 14 to 16 November 2012.

\section{THE BEGINNINGS OF PHYSICAL OCEANOGRAPHY}

Spain and Portugal were undoubtedly the leading countries in the maritime discovery of new lands between the $15^{\text {th }}$ and 17 th centuries, but it was not until the second half of the 18th century that scientific ocean expeditions started. In this section we briefly review the major early oceanographic ventures and summarize the landmarks in physical oceanography up to the Second World War. We do not aim to be exhaustive on the world history and development of physical oceanography, as there are a number of far more detailed publications on this topic (e.g. Stommel 1989, Deacon 1998, Munk 2002, Jochum and Murtugudde 2006, Talley et al. 2011). Rather, we wish to place the Spanish advances within this global perspective.

The early scientific expeditions included James Cook's voyages between 1768 and 1780, Alejandro Malaspina's expedition around the Pacific Ocean (1789-1794), Alexander von Humboldt's voyage to South and Central America (1799-1804), the Beagle's expedition around the world with Charles Darwin on board (1831-1836), the United States expedition to the Pacific Ocean and the South Seas led by Charles Wilkes (1838-1842), and the round-theworld voyage of the Challenger under the scientific direction of Wyville Thomson (1872-1876). These expeditions focused mainly on natural studies and cartographic calculations and measured only a few physical parameters, such as water depth in shelf waters, tidal range, surface temperatures and currents; in some cases they also measured subsurface temperatures using pseudo-protected thermometers. These expeditions, often promoted for political and strategic reasons, included major scientists who later published useful reports and promoted further research in their countries.
The Spanish expedition of Malaspina was unfortunately the exception. Alejandro Malaspina suggested that, rather than maintaining an empire, Spain should develop a confederation of states for international trade (Black and Manfredi 2007). This opinion was apparently not shared by the Spanish monarchy and Malaspina fell into disgrace. One year after his return Malaspina was arrested and sentenced to ten years in prison, although in 1803 the sentence was commuted to exile. Malaspina died in 1810 and, sadly, the expedition materials and reports were destroyed (Pimentel 2011). As a result, this early expedition had little or no influence at all on the early development of Spanish oceanography, although a recent global circumnavigation expedition (2010-2011) explored global change and biodiversity in the world oceans in commemoration of Malaspina's original voyage (Puig-Samper and Rebok 2011).

In the last half of the 19th century Matthew Maury, a United States naval officer, provided the first example of the potential social benefits of physical oceanography through the gathering and analysis of oceanographic data. Maury examined the United States Navy ship logs and drew charts of winds and surface currents, published in 1885, that helped optimize ship routes. The publication was very successful inside and outside the United States and was probably the first milestone towards international cooperation in the compilation of marine observations. It prompted many countries, including Spain, to send ship logs to the United States Naval Observatory, where they were analysed and distributed worldwide.

Physical measurements in the ocean really started in the Scandinavian countries in the early 1890s with reverse thermometers (introduced by Negretti and Zambra in 1874) and some of the first salinity measurements. The first major figure was the Norwegian Fridtjof Nansen, who led the expeditions to the Arctic Ocean (1893-1896) and later received the Nobel Peace Prize for his humanitarian tasks following the First World War. Nansen attached reverse thermometers to bottles which were used to obtain water samples for salinity analysis - what became known as the Nansen bottle and eventually developed into the modern $\mathrm{Ni}$ skin bottle. The Bergen school, with scientists initially trained as meteorologists, pioneered the beginning of theoretical physical oceanography and observations in the Norwegian Sea. Nansen, the Bjerkness family, Johan Sandström, Walfrid Ekman and Bjorn HellandHansen were some of the early names, in addition to Harald Sverdrup and Carl Gustav Rossby.

Other influential contemporaneous European oceanographers were the Dane Martin Knudsen and the Briton Joseph Proudman (a pupil of Horace Lamb). However, it was the German school, with Alfred Merz, George Wüst and Albert Defant, that led the physically oriented deep-ocean expeditions. This school proposed the early patterns of subsurface and deep circulation in the Atlantic Ocean, which were not much differ- 

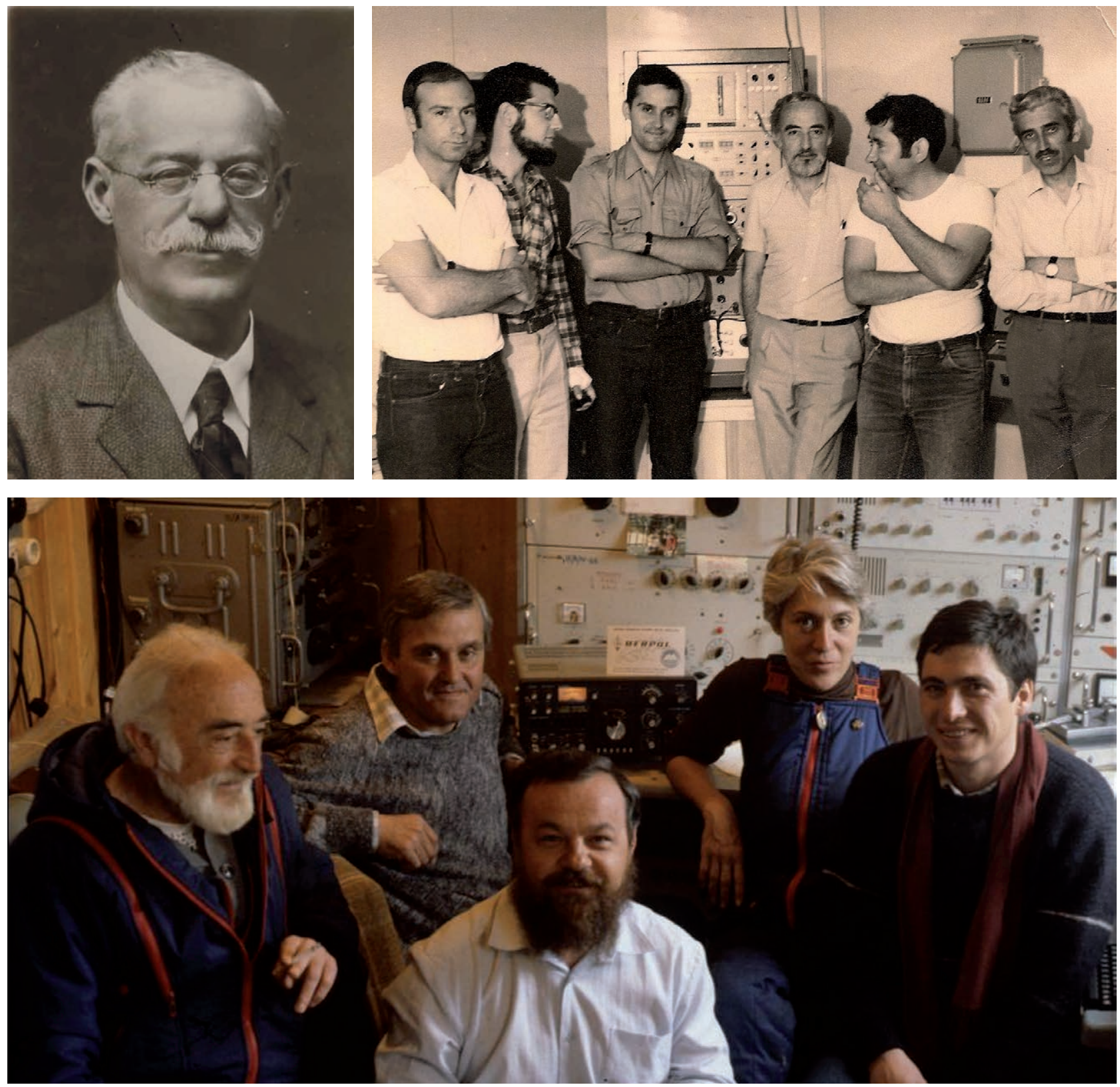

FIG. 1. - (Top left) Odón de Buen (1863-1945), founder of the IEO, picture taken in 1936. Source: IEO. (Top right) From left to right: Josep Martínez, Jaume Rucabado, Agustí Julià, Antoni Ballester, Antoni Cruzado and Carles Bas on board the RV Cornide de Saavedra during the Sahara I cruise (1971), the first one carried out by this vessel off NW Africa during the CINECA experiment. (Bottom) The first Spanish oceanographers in the Antarctica, from left to right Antoni Ballester, Agustí Julià, Walter (a member of the Polish base), Josefina Castellvî and Joan Rovira (Polish Base Henryk Arctowski, King George Island, Antarctica, in 1986). On 27 December 1986 the first Spanish camp was installed and in March 1988 a Spanish base was established on Livingstone Island, allowing Spain to enter the Antarctic Treaty. A colour version of this figure may be found in the online electronic manuscript.

ent from present conceptions (Richardson 2008), and obtained the first ocean-wide set of physical measurements with the Atlantic expedition of the RV Meteor (1925-1927). At this time physical oceanography made a great step forward in the United States when a series of biological laboratories formed the Scripps Institution of Oceanography in 1923 and the Woods Hole Oceanographic Institution (WHOI) in 1930. Harald Sverdrup became the WHOI director in 1936, thus catalysing further research in physical oceanography.
The development of physical oceanography in Spain followed quite a different path. The late 19th century was a period of cultural enlightenment in Spain. The European revolution, although delayed, had finally arrived and the development of natural sciences with it. The timing was good for catching up with the international development of oceanography. A clear sign of the interest in natural sciences in general, and marine sciences in particular, was the existence at the time of private oceanographic societies in Corunna (1906), Bar- 
celona and San Sebastian (both in 1908), and Almeria (1916) (Pérez-Rubín Feigl 2011). The development of marine sciences in Spain was favoured by two main figures: Augusto González de Linares, who established a Maritime and Botanical Station (Estación Marítima y Botánica) in Santander in 1886, and Odón de Buen y del Cos (Sánchez-Carrillo 2001, Duarte et al. 2006) (Fig. 1). Odón de Buen studied oceanography at the University of Bordeaux and later worked at the Laboratory of Banyuls, where he made friends with the marine biologist Henri de Lacaze-Duthiers and with Prince Albert I of Monaco. This helped him establish a marine laboratory in Mallorca (1906) and Málaga (1912). Shortly afterwards (1914) these two laboratories and the Santander station merged to become the Spanish Institute of Oceanography (Instituto Español de Oceanografía, IEO), with de Buen as its first director (IEO 1989, Pérez de Rubín 2004).

Spanish oceanography flourished in the early twentieth century: the constitutive assembly of the International Commission for the Scientific Exploration of the Mediterranean Sea (CIESM) was held in Madrid (1919), Spain became a member of the International Hydrographic Bureau (1921) and the International Council for the Exploration of the Seas (1924), and three international meetings on oceanography were held simultaneously in Seville (1929), with Albert Defant and Harald Sverdrup among other distinguished speakers. A major initiative was the creation of an Ibero-American oceanographic commission, including Portugal and Spain; several meetings were held but the project never got the approval of all participating countries. Unfortunately, the Spanish Civil War (1936-39) put an end to these developments because of the economic repercussions and because some of the leading marine scientists, including Odón de Buen and his two sons Alfonso and Rafael, went into exile after the war (Sanchez-Carrillo 2001).

\section{PROGRESS DURING THE LAST HALF CENTURY}

During the first few decades of the 20th century the main current systems and the fundamentals behind the dynamic method and wind-induced transport were reported in two major works: Physikalische Hydrodynamik (Bjerkness et al. 1933) and The Oceans (Sverdrup et al. 1942). Prompted by the developing military needs just before and during the Second World War, physical oceanography underwent great progress. Wind waves, in particular, moved into a higher level of development because of the need for accurate maritime weather forecasting during the landing of the Allies on the beaches of Normandy. This was possible through the acquisition of many data and the development of the theories of sea turbulence (Andrey Kolmogorov in 1941), ocean surface waves (George Deacon and others during the 1940s) and circulation in the ocean interior and western boundaries (Harald Sverdrup in 1947, Henry Stommel in 1948 and Walter Munk in 1950).
Physical oceanography continued to advance swiftly after the Second World War. The following decades saw the advent of numerous quantitative theories: the Equatorial Undercurrent (Nick Fofonoff and Raymond Montgomery, 1955); abyssal circulation (Stommel and Arnold Arons in the late 1950s and early 1960s); mixing through double diffusion (Stommel in 1956 and Melvin Stern in 1960); the transfer of energy in the ocean, either into surface wind waves (Sverdrup and Munk in 1947, John Miles and Owen Phillips in 1957, and Klaus Hasselman in 1960) or into internal waves (Chris Garret and Walter Munk, 1957); the global El Niño-Southern Oscillation connection (Jacob Bjerkness, 1960); isopycnal thinking, pioneered by Raymond Montgomery (1937) and later popularized by Denny Kirwan (1963) and Joseph Reid (1964); and wind-driven coastal circulation (Gabriel Csanady, late 1960s and 1970s).

The precision of ocean measurements has improved thanks to three major developments that have taken place since the 1960s (Dickey and Bidigere 2005, Wangersky 2005). The first development was the advent of multiple continuous recording instruments, which can be ship-borne, moored or autonomous. Major examples are multi-parametric probes, in situ or remote (usually acoustic) velocity current meters, and autonomous vehicles (drifters, profilers and gliders). In some applications these instruments are capable of sampling at very high frequencies, leading early to the discovery of microstructure (for a review see Lueck et al. 2002). They can also store internally large amounts of data, allowing near-continuous measurements and long instrumental deployments at sea. The second development was that of satellite-borne sensors, beginning in the mid-1970s with sea surface temperature measurements from the National Oceanic and Atmospheric Administration satellites. Today there are satellite sensors for sea surface colour, temperature, winds, waves, mean height and-since 2009 - salinity. These sensors have led to extensive quasi-instantaneous spatial coverage with different degrees of spatial resolution, in some instances allowing variability to be identified at the mesoscale and even the sub-mesoscale. However, they remain limited in coastal seas where the land-sea transition may results in a shadow area where the recovery of information from remote images is still an ongoing research field. The third development was the use of numerical models to reproduce physical oceanic processes, made possible through the appearence of digital computers and the exponential growth of computer power. Lewis Richardson's early efforts on numerical weather forecasting, made at the beginning of the century, became a reality for the oceans. All facets of physical oceanography have benefited from these models, but in particular the simulation of ocean circulation, following the pioneering works by Kirk Brian and Michael Cox (1968) and James O'Brien (1970), and the forecast of the state of sea surface waves, from SWAMP in the late 1970s to the third-generation 

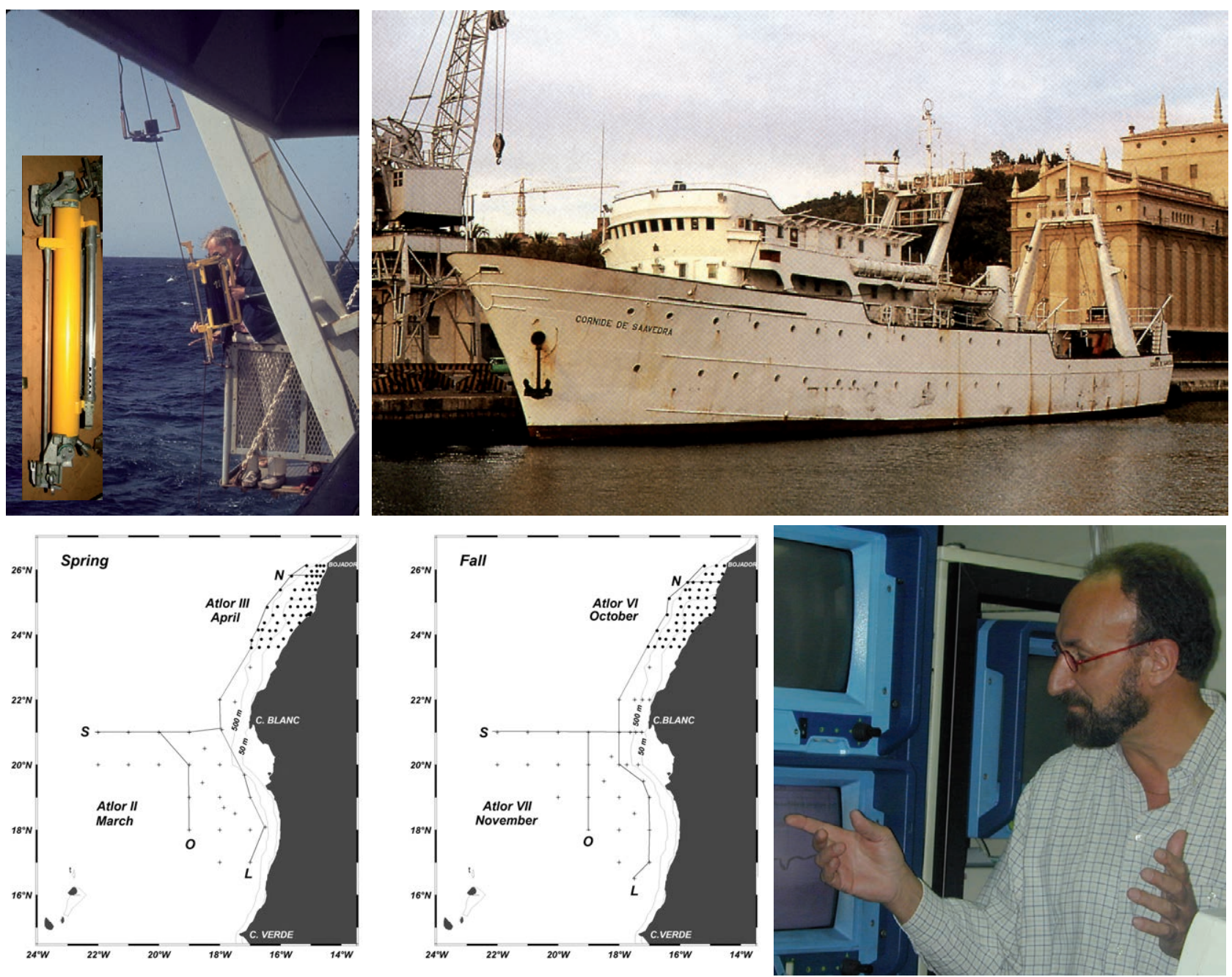

FIG. 2. - (Top left) Antoni Ballester deploying a modified Nansen bottle from the RV Cornide de Saavedra off NW Africa (1970s). Source: Jordi Salat, ICM. The inset shows a detail of the Nansen bottle. Source: Juan Pérez-Rubín, IEO. (Top right) The RV Cornide de Saavedra in 1983, in the port of Málaga. Source: Juan Pérez-Rubín, IEO. (Bottom left) Stations during the Atlántico Oriental (ATLOR) cruises II, III, VI and VII, carried out with the RV Cornide de Saavedra off NW Africa in 1975 and 1978; reproduced from Pastor et al. (2008) with permission from Elsevier. (Bottom right) Mario Manríquez Landoff, one of the technicians who participated in the early CINECA cruises, has participated in the design and setup of several Spanish research vessels. Source: UTM.

models regularly discussed at the international Waves in Shallow Environments meetings, the last one held in Barcelona. The waves and current models, working in nested sequences or using non-structured grids, are now used for routine predictions in several operational centres (for a recent report, see Federal Maritime and Hydrographic Agency [2011])

These developments were enhanced by the onset of intense international collaboration. A series of major cooperative observational programmes started with the International Geophysical Year (1957-58), followed by the International Indian Ocean Expedition (1959-1964) and several major experiments as part of the International Decade of Ocean Exploration (IDOE, 1971-1980), including the Mid-Ocean Dynamics Experiment, the Joint North Sea Wave Project and the Geochemical Ocean Sections Study (UNESCO 1974). These programmes were followed by the
World Climate Research Programme (1980), which eventually led to large field programmes such as the Tropical Ocean Global Atmosphere programme (since 1985) and the World Ocean Circulation Experiment (WOCE, with field measurements during 1990-98). The importance of WOCE lies in the coordination of cruises worldwide in a single decade, therefore providing a much improved view of the general circulation of all oceans, and in the establishment of systematic protocols that ensured the accuracy of the observations. WOCE truly marked the beginning of international databases with freely available quality data.

At the end of last century, the need for more accurate ocean forecasting led to the appearance of operational oceanography as a field on its own, in which research institutions and governmental agencies work together to establish observing systems and assimilate ocean data into numerical models. Henry Stommel had envisioned 
this panorama when he wrote the following (Stommel 1989): "Looking into the future beyond 20 years of WOCE, I think that we will see establishment of a regular oceanic data network, using remotely controlled vehicles to make routine subsurface measurements on a global scale, like that of the meteorological network. Presumably such regular data-collecting systems will eventually be taken over by responsible government agencies, and the research community will be relieved of taking much of these climate-motivated data. They will feed the hungry computers. But certainly we will always need ships to do our work in the ocean." At present, the most important worldwide observing system is Argo (www.argo.ucsd.edu), a global array of temperature and salinity profilers which began in 2001 and has some 3500 units transmitting in real time from the ocean. These and other data sets, particularly from satellites and research and opportunity vessels, are regularly incorporated into global operational models that are used for both forecasting and research. Some European examples of operational systems are the Coriolis Operational Oceanography initiative (www.coriolis.eu.org) and the European Ocean Monitoring and Forecasting system (MyOcean and MyOcean2, www.myoecan.eu), in the framework of the Global Monitoring for Environment and Security (GMES, www.gmes.info) programme for the establishment of a European capacity for Earth observation.

Following the Civil War, Spain experienced a period of intellectual isolation, with a very slow recovery of science in general and physical oceanography in particular. In 1943 the Navy Hydrographic Institute (Instituto Hidrográfico de la Marina, IHM) was created from previous bodies in charge of hydrographic and bathymetric duties. The development of the IEO did not continue until the late 1960s but meanwhile, as a consequence of the important fisheries off NW Africa in the former Spanish Sahara, some fisheries-oriented research began. In 1951 the Fisheries Research Institute (Instituto de Investigaciones Pesqueras, IIP) was created within the Spanish National Research Council (Consejo Superior de Investigaciones Científicas, CSIC). It was based in Barcelona and had coastal laboratories in Blanes, Castelló, Vinaròs and Vigo (Guerra and Prego 2003, 2011; Duarte et al. 2006). In 1978 the IIP split into several research centres, the most important ones being the Institute of Marine Sciences (Institut de Ciències del Mar, ICM) in Barcelona, now the largest Mediterranean marine science centre, and the Marine Research Institute (Instituto de Investigacións Mariñas, IIM) in Vigo. These institutes had two leading figures: the ecologist Ramón Margalef and the chemist Fernando Fraga, respectively. Other marine centres created during this period and carrying out research on physical oceanography are the Canaries Institute of Marine Sciences (Instituto Canario de Ciencias Marinas, ICCM, created in 1974) in the Canary Islands, the Marine and Food Technology Centre (Instituto Tecnológico Pesquero y Alimentario, AZTI, created in 1981) in the Basque country and the Mediterranean Institute for Advanced Studies (Instituto Mediterráneo
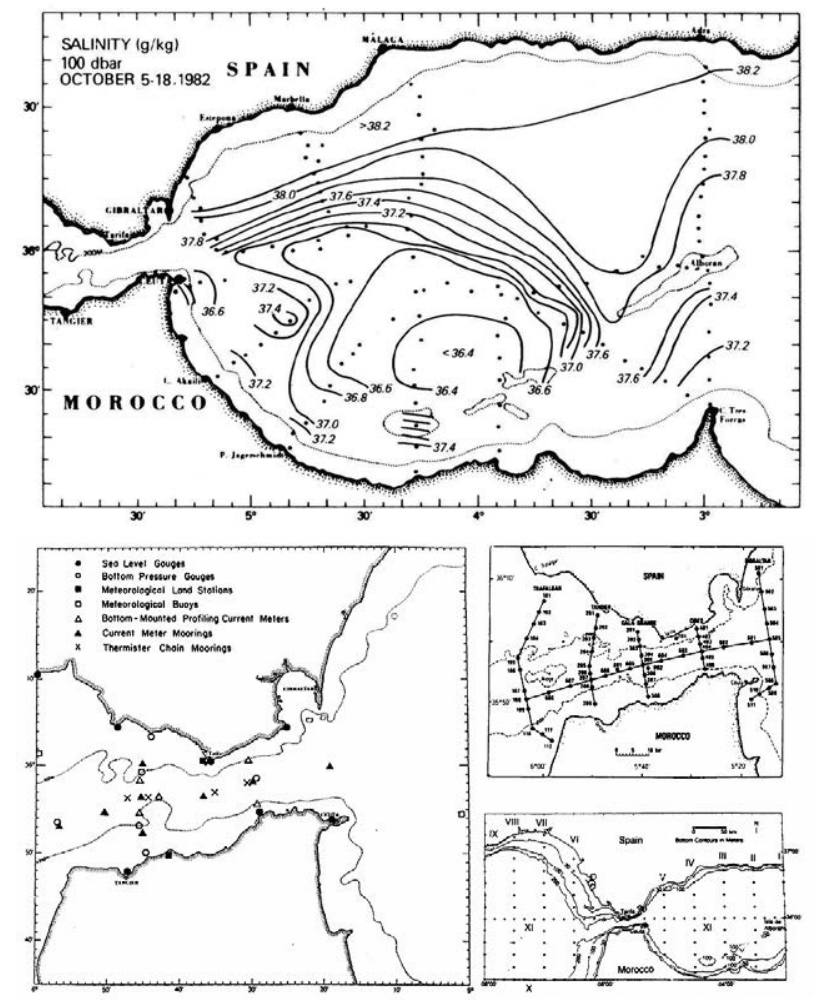

FIG. 3. - (Top) The "Donde Va?" experiment, carried out between June and October 1982, included surveys and moorings in the Alboran Sea, with the participation of Spanish scientists from the IEO and the IHM; reproduced from Donde Va group (1984). (Bottom) The Gibraltar Experiment was a large international effort aimed at studying the Atlantic-Mediterranean exchanges in the Strait of Gibraltar; reproduced from Bryden and Kinder (1986) and Kinder and Bryden (1988) with permission from Woods Hole Oceanographic Institution.

de Estudios Avanzados, IMEDEA, created in 1985) in the Balearic Islands.

Two circumstances helped the recovery of Spanish oceanography during the 1970s. The first one was the great increase in fishing off NW Africa during the 1960s. The first Spanish oceanographic vessel, RV Cornide de Saavedra, was built in 1970 (Fig. 2) and Spain became quite active studying the upwelling system off NW Africa (Figs. 1 and 2). An International Symposium on Upwelling Systems was held in 1970 in Barcelona in the framework of IDOE and a major programme, the Cooperative Investigation of the Northern Part of the Eastern Central Atlantic (CINECA), was created (Margalef 1971). As part of CINECA some 100 scientific cruises off NW Africa were carried out by several European countries and the United States between 1970 and 1977, including nine cruises on board the RV Cornide de Saavedra (Hempel 1982). The second major milestone was the cooperative treaty signed in 1976 by the United States and Spain, which represented an opportunity for enhanced collaboration with leading oceanographic institutions, including the exchange of scientists and the possibility of purchasing new instruments. This provided a great impulse to the development 

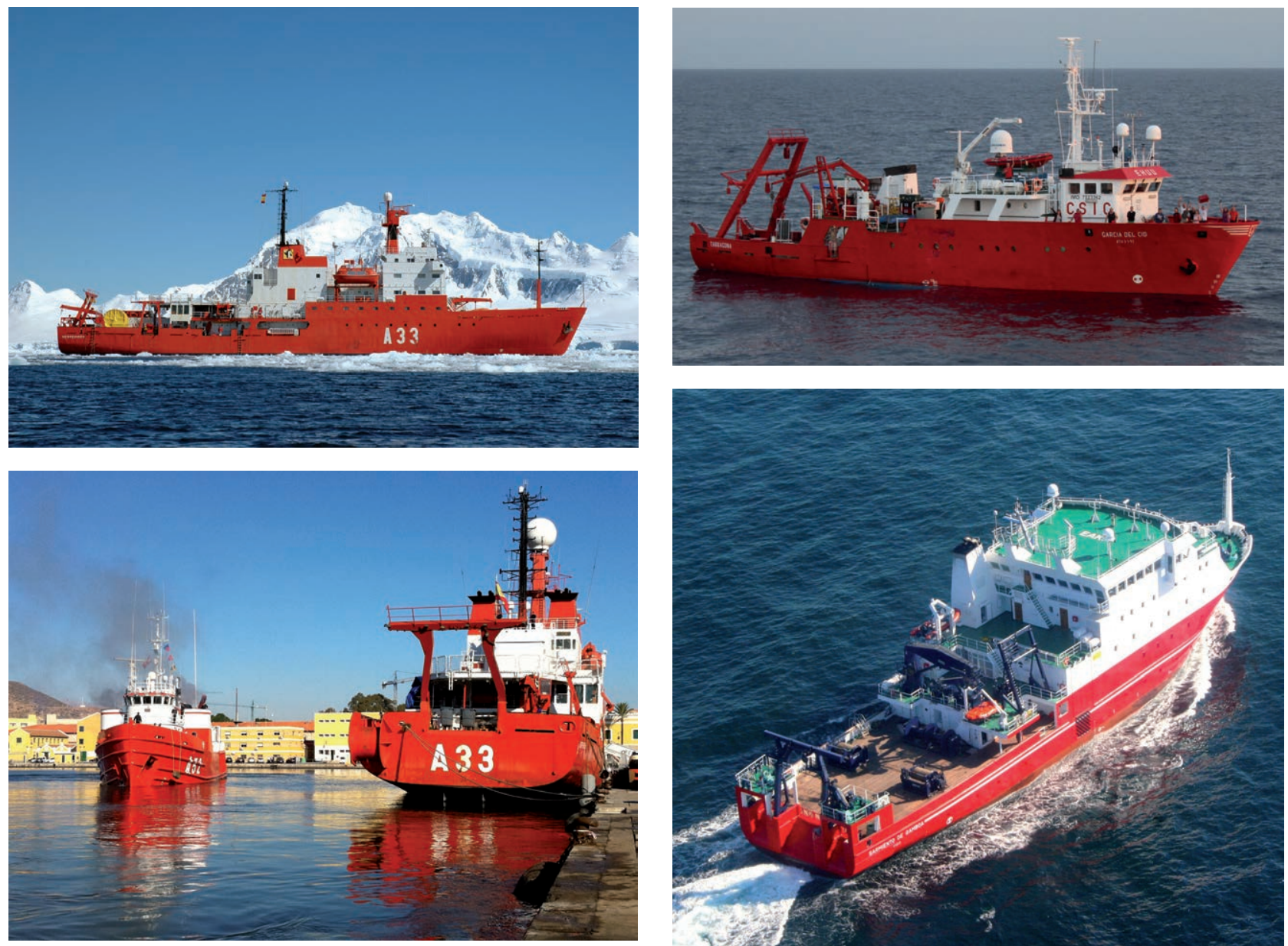

FIG. 4. - The main vessels used by the Spanish physical oceanography community: (top left) side view of RV Hespérides, with polar capabilities; (top right) RV García del Cid; (bottom left) RV Las Palmas, used mainly to supply the Antarctic bases, together with a rear view of RV Hesperides; and (bottom right) aerial view of RV Sarmiento de Gamboa. Source: UTM.

of observational programmes in the Strait of Gibraltar and Gulf of Cádiz as well as in the rias and on the continental shelf off Galicia, among others. The "Donde va?" project (Parrilla 1984) was carried out in summer 1982 through collaboration between the IEO, the IHM and several European and American research centres, and it became the basis for the comprehensive Gibraltar Experiment, carried out in 1985-1986 (Ruiz Cañavate $e t$ al. 1986, Kinder and Bryden 1988) (Fig. 3).

A key element for the growth of Spanish oceanography has been the construction of two large oceanographic vessels, which have been instrumented with state-of-the-art oceanographic equipment. These vessels, available through competitive national programmes, are RV Hespérides (1991) and RV Sarmiento de Gamboa (2006). In particular, the installation of the first Spanish base in Antarctica in 1988 and the building of the ice-strengthened RV Hespérides marked the start of a major Antarctic research programme which still continues (Fig. 4). The modern RV Sarmiento de Gamboa came 25 years later, at the right time to meet the very much increased demand for ship-time by the Spanish oceanographic community (Fig. 4).
Recently the IEO has added to its fleet several modern, multi-purpose oceanographic ships: RV Thalassa (built in 1996 and belonging to the IEO and the French Research Institute for Sea Exploitation, IFREMER), RV Ramón Margalef (2011) and RV Angeles Alvariño (2012) (Fig. 5). There are also several medium-size vessels run by public institutions and universities and sometimes available to the whole community, which have been very effective for conducting extensive sampling in coastal regions. One such example that deserves special mention is the RV García del Cid (1977), which has led many expeditions in shelf and open waters, especially in the Mediterranean Sea (Fig. 4). Another example is the RV Mytilus (1996), largely dedicated to sampling the Galician rias (Fig. 5). The creation in 2000 of the CSIC's Marine Technology Unit (Unitat de Tecnologia Marina, UTM) was of fundamental importance for the sea-going oceanographic community as it provides logistic and technical support to the scientific staff in the oceanographic vessels and the two Spanish Antarctic bases.

This fleet of oceanographic ships has driven the Spanish advance in physical oceanography in several 

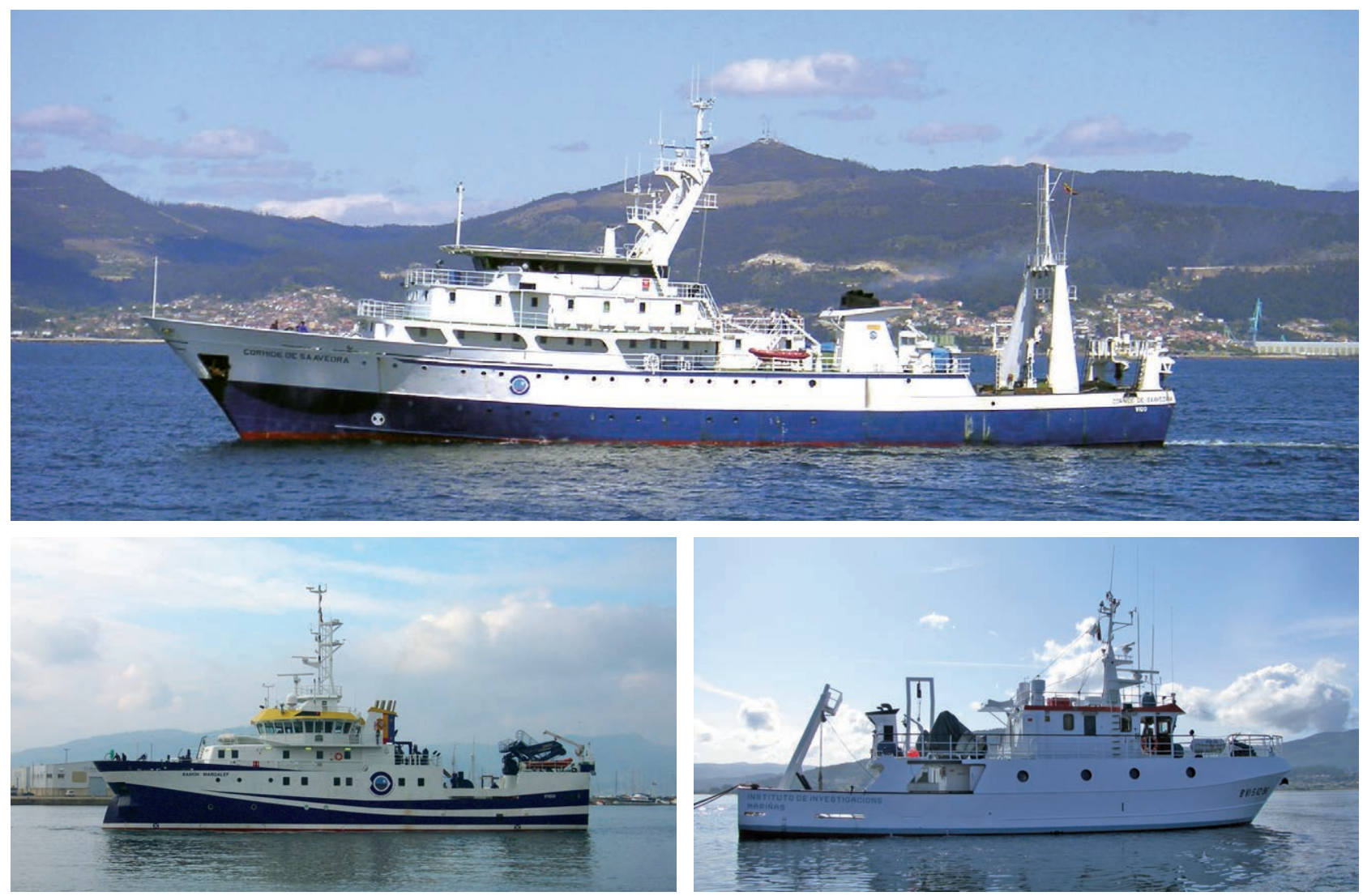

FIG. 5. - The IEO has several multi-purpose vessels, such as (top) RV Coornide de Saavedra (after changing engines in winter 1982/83, lengthening in 1985 and renovation of its superstructure in 1989), and (bottom left) the new RV Ramón Margalef. Source: IEO. (Bottom right) Several institutions have well-instrumented small-size vessels, such as the RV Mytilus, built in 1996 and operated by the IIM. Source: IIM.

directions. First, the undertaking of comprehensive field experiments in Spanish and international waters has led to substantial improvements in our knowledge of regional dynamics and oceanographic processes (Figs. 6 to 10). Second, the accomplishment of repeated transatlantic (Fig. 11) and near-shore (Fig. 12) oceanographic sections has contributed to our current understanding of climate change. Some of these cruises were carried out as part of the WOCE programme: the repeated $24^{\circ} \mathrm{N}$ transatlantic section and the seasonal cross-shore transects started by the IEO in 1987, initially off Vigo (Galician coast) and progressively extending to many other locations in Spanish waters. A third major contribution has been the installation and maintenance of long-time monitoring stations, such as the ESTOC mooring north of the Canary Islands (ICCM and the University of Las Palmas de Gran Canaria [Universidad de Las Palmas de Gran Canaria, ULPGC]), the EBC-4 mooring between the Canary Islands and the African coast (IEO and ULPGC), the Espartel Sill mooring (western Gibraltar, maintained by the University of Malaga [Universidad de Málaga, UM]; Fig. 13) and the Barcelona and Cap de Creus moorings (Catalan Sea, maintained by ICM) (these last three being part of the CIESM HydroChanges programme). A fourth direction has been through active participation in international sampling programmes. A central example of this participation is the Spanish con-
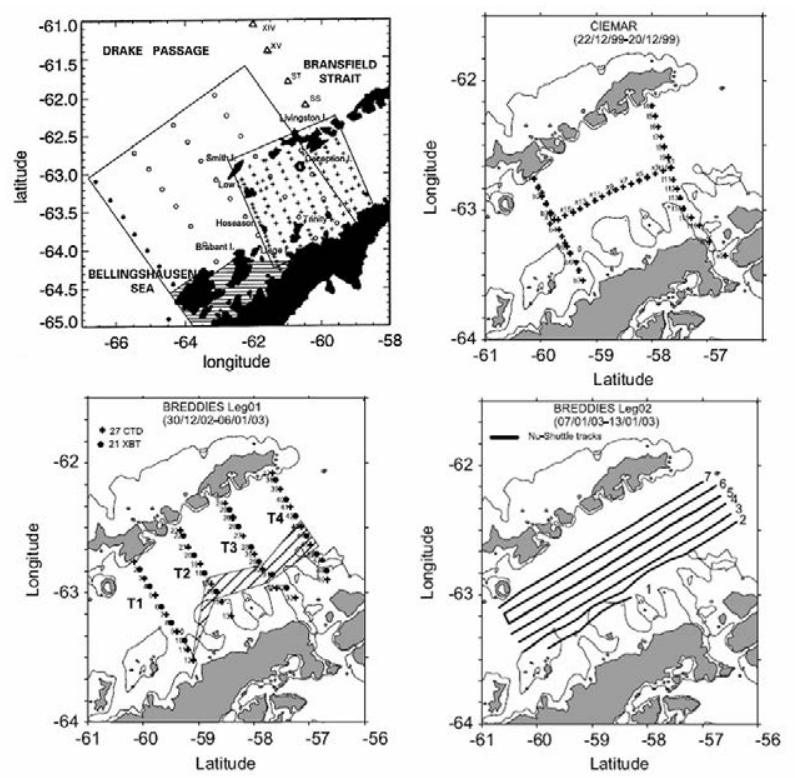

FIG. 6. - The RV Hespérides has allowed the Spanish community to become actively involved in Antarctic research, with intensive sampling in the Bransfield Strait. (Top left) FRUELA cruises during the austral summer of 1995-96; reproduced from Gomis et al. (2002) with permission from Elsevier. (Remaining panels) The CIEMAR and BREDDIES cruises in December 1999 and January 2003, respectively; reproduced from Sangrà et al. (2011) with permission from Elsevier. 

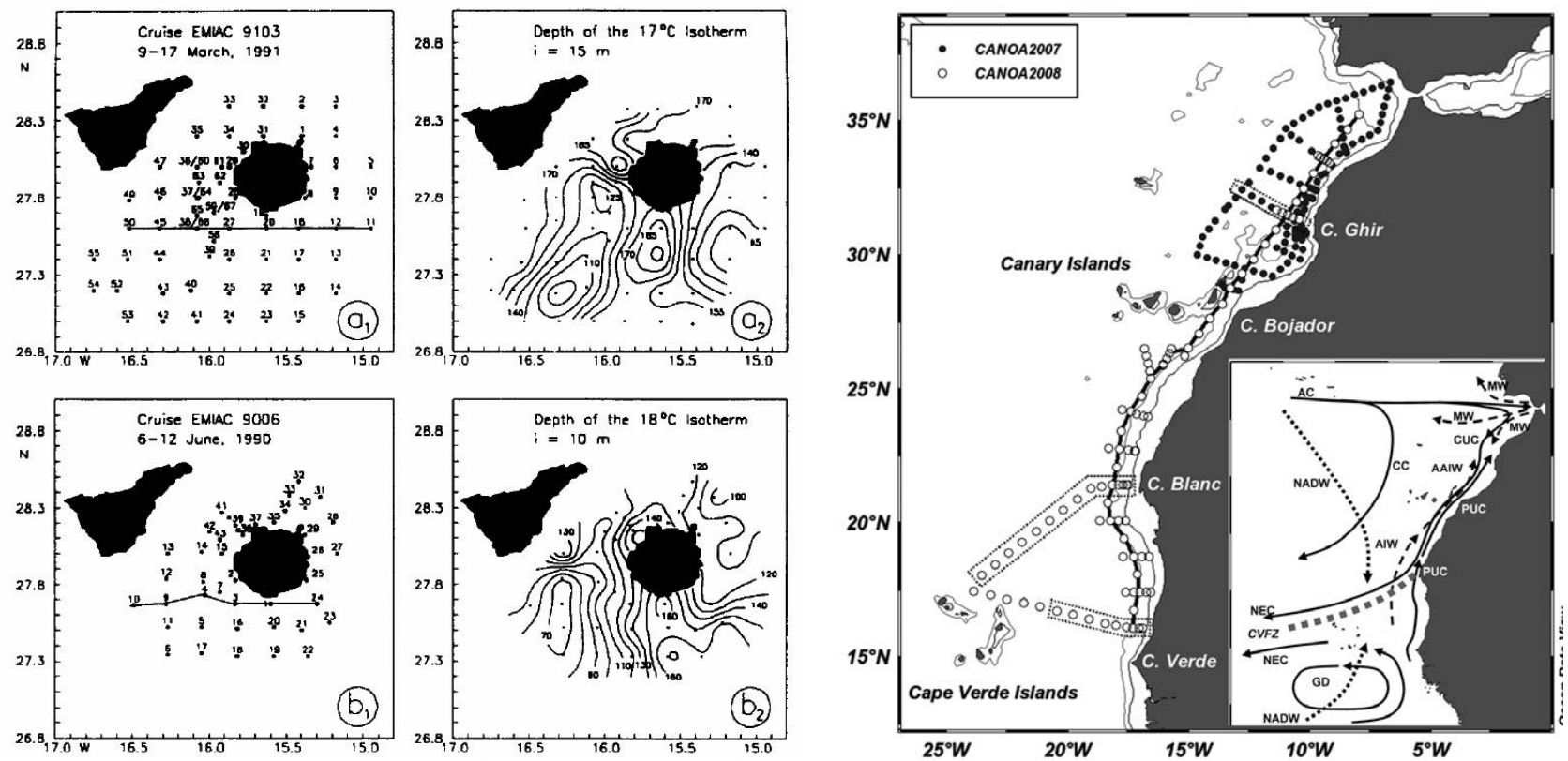

FIG. 7. - (Left panels) Several cruises in the 1990s intensively sampled the eddies found south of the Canary Islands, some of them carried out by the RV García del Cid; reproduced from Arístegui et al. (1997) with permission from Elsevier. (Right) Large-scale sampling off NW Africa carried out with the RV García del Cid (November 2007) and RV Sarmiento de Gamboa (November 2008); the inset depicts the principal large-scale currents in the region; reproduced from Pastor et al. (2012) with permission from Ciencias Marinas.
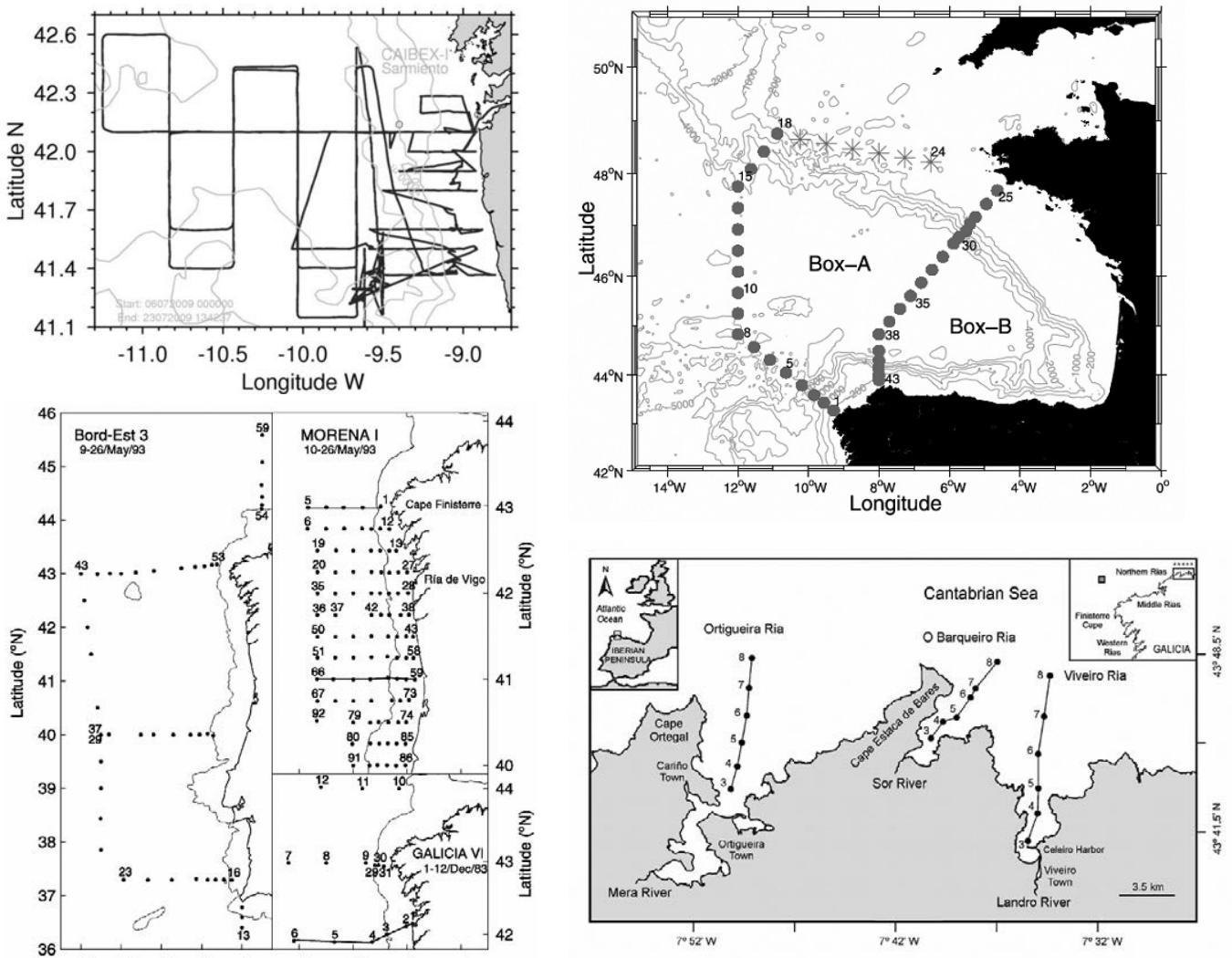

FIG. 8. - (Top left) Track of RV Sarmiento de Gamboa during the CAIBEX-I (July 2009) cruise off the Galicia coast. Sampling consisted of a combination of large-scale sections to get the background field and several cross-shore sections over the shelf and slope, plus the installation of moorings (red dots) and the launching of drifters over the shelf; reproduced from Barton (2009) with permission from the author. (Bottom left) A study of the Portugal boundary current system was done using data from several vessels, including the RV Coornide de Saavedra (MORENA I) and the RV García del Cid (GALICIA VI); reproduced from Pérez et al. (2001) with permission from Elsevier. Other vessels have been extensively used during recent years: (top right) the French-Spanish RV Thalassa, reproduced from Fraile-Nuez et al. (2008); (bottom right) the smaller RV Mytilus (CSIC) and RV Lura (IEO), reproduced from Ospina-Álvarez et al. (2010) with permission from Elsevier. 

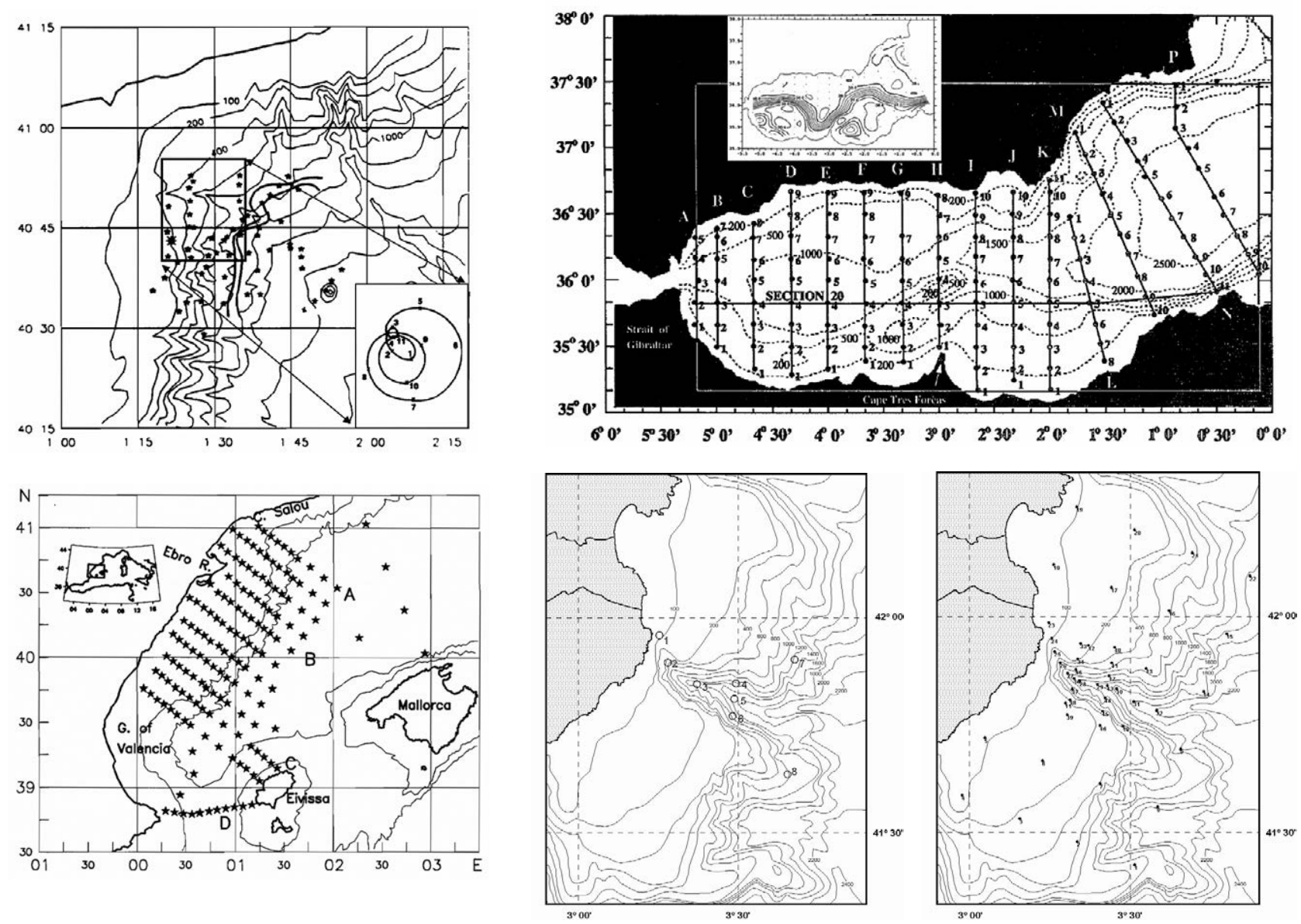

FIG. 9. - The RV García del Cid has been instrumental in sampling the waters near the Iberian Peninsula. Several Wandering Drifter (Flotadors Errants) cruises were carried out in the north-western Mediterranean, among them (top left) the June 1987 cruise (65 hydrographic stations, five radio-tracked surface drifters and one mooring), reproduced from Salat et al. (1992), and the (bottom left) May-June 1991 cruise (158 stations plus ship-borne velocity and aerial bathythermograph measurements), reproduced from Salat (1995) with permission from Elsevier. (Top right) Hydrographic stations sampled in the Alboran Sea in September-October 1992; reproduced from Viudez et al. (1996). (Bottom right) A series of field measurements were carried out in the Palamós canyon between March and November 2001, including moorings (left) and four cruises with hydrographic stations such as the one here shown (right); reproduced from Palanques et al. (2005) with permission from Elsevier.
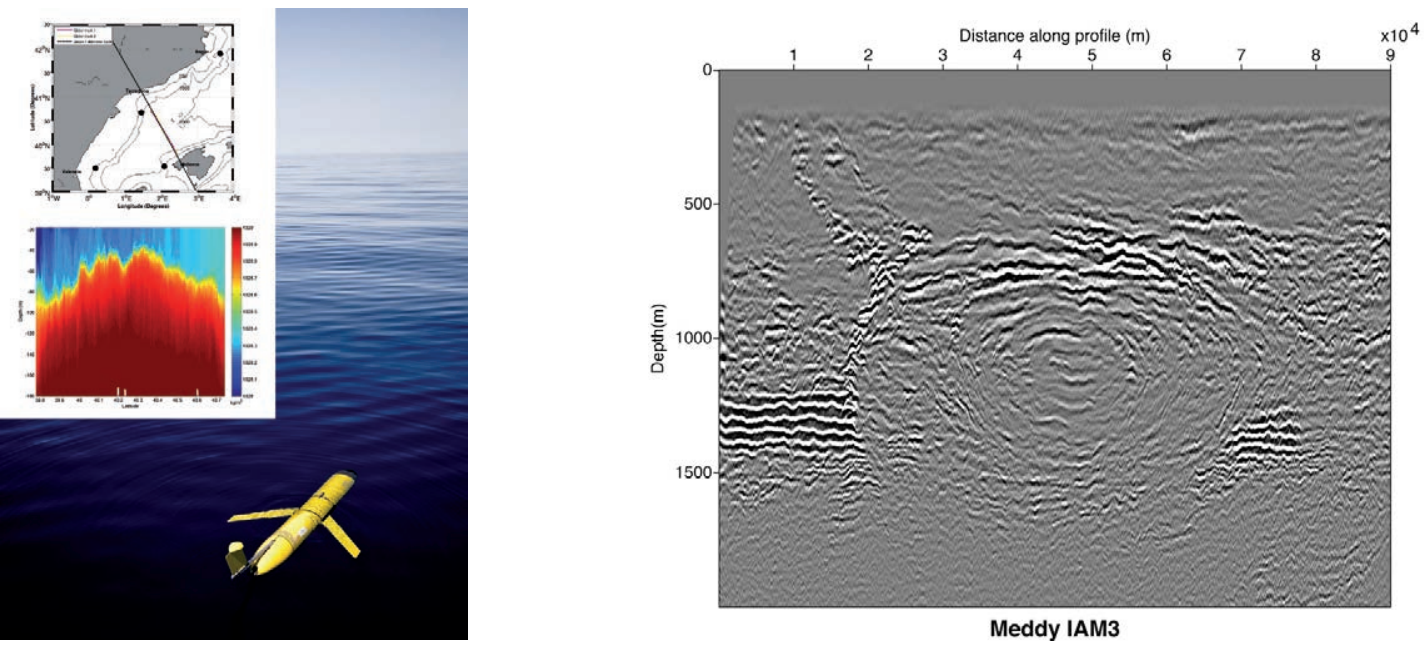

FIG. 10. - State-of-the-art approaches for high-resolution horizontal sampling. (Left) Gliders are becoming part of the research and operational tools developed at SOCIB. The picture illustrates a unit beginning its trip near the Balearic Islands (Source: S. Ruiz, SOCIB); the inset shows the path followed and the sampled density field, reproduced from Ruiz et al. (2012) with permission of Elsevier. (Right) Seismic oceanography is a powerful technique for deciphering the internal structure of the ocean at vertical and horizontal resolutions of the order of $10 \mathrm{~m}$; reproduced from Biescas et al. (2008). 

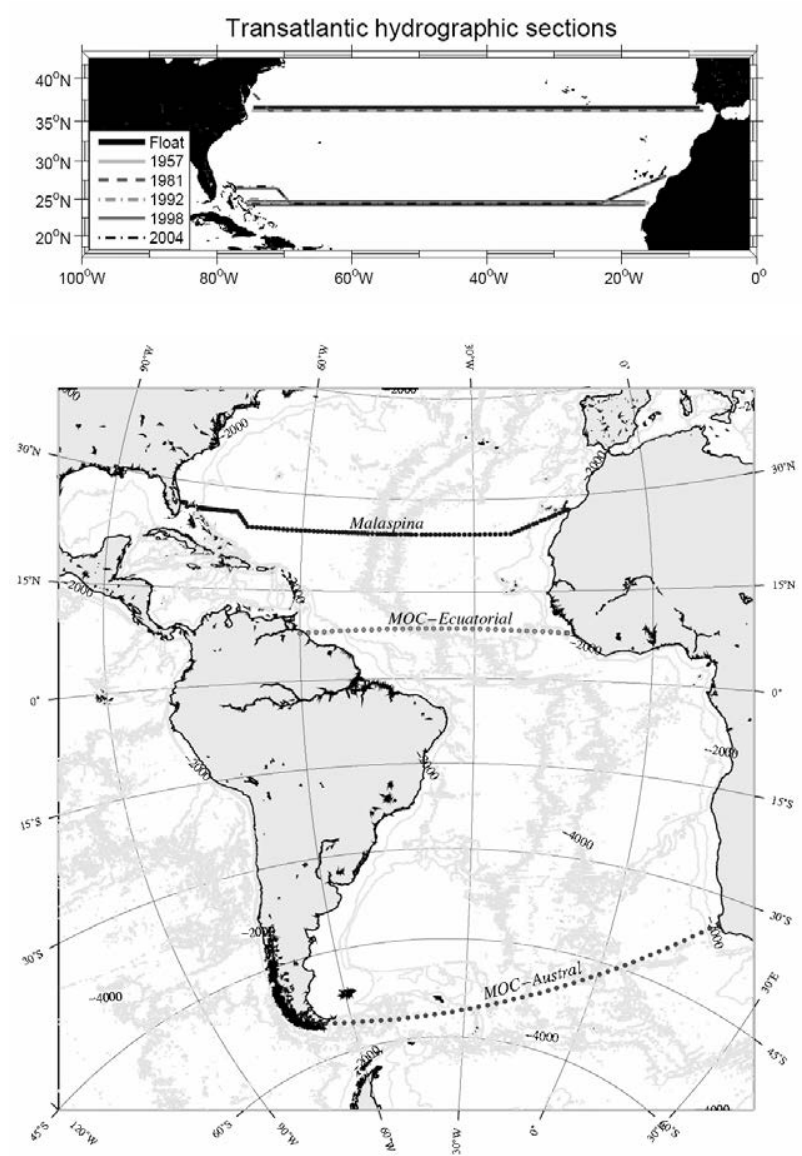

FIG. 11. - (Top) Several of the repeat North transatlantic sections have been carried out with Spanish vessels, starting with the 1992 WOCE A05 section (Parrilla et al. 1994) on board the RV Hespérides; reproduced from Hernández-Guerra et al. (2010) with permission from Elsevier. (Bottom) Schematics of the location of three recent transatlantic sections: MOC-Austral and MOC-Ecuatorial (2010, RV Hespérides), and Malaspina (2011, RV Sarmiento de Gamboa). Source: Alonso Hernández Guerra, ULPGC.

tribution to the Argo programme led by the IEO, with the participation of several other institutions, in which many profilers have been purchased and deployed mainly in the Mediterranean and northern Atlantic. One important outcome of these repeated measurements, supported by other singular initiatives such as the temperature data gathered off Estartit (north-western Mediterranean) since in 1973, has been the creation of time series sufficiently long to assess the sign and size of inter-annual and inter-decadal ocean changes (Vargas Yañez et al. 2007; Bode et al. 2012).

In the 1990s other large facilities were built, some of them qualifying as European Union singular research facilities. These included several large tanks and wave channels at the Public Works Centre for Studies and Experimentation (Centro de Estudios y Experimentación de Obras Públicas, CEDEX), at the El Pardo Channel for Hydrodynamic Experiences (Canal de Experiencias Hidrodinámicas de El Pardo, CEHIPAR), and at the Maritime Engineering Laboratory of BarcelonaTech (Laboratorio de Ingeniería Marítima, of the Universitat
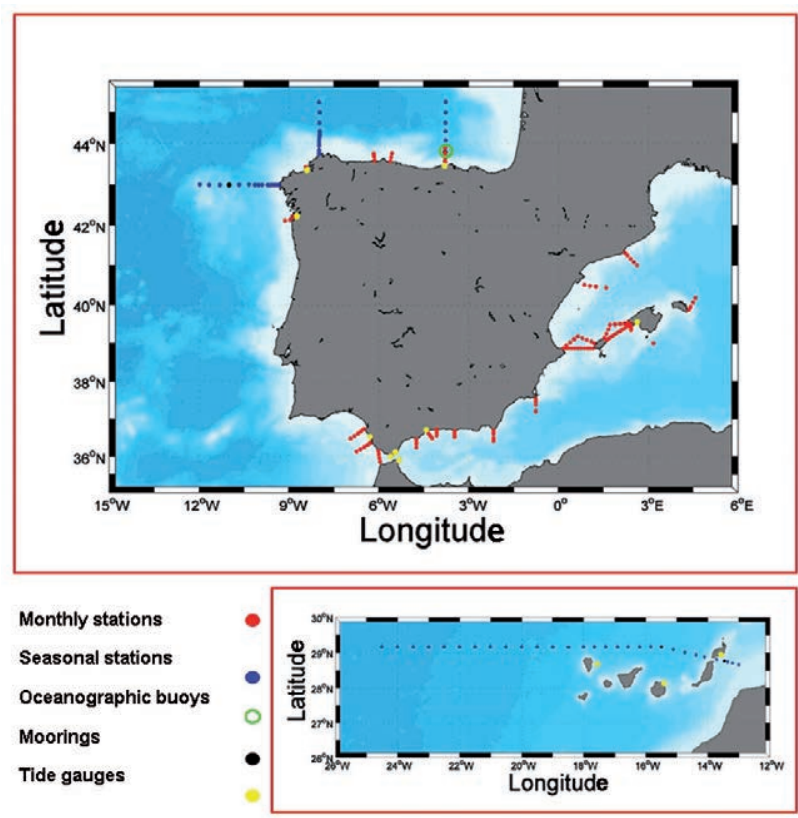

FIG. 12. - Periodic measurements (top) around the Iberian Peninsula and (bottom) near the Canary Islands, as maintained by the IEO. Source: IEO. A colour version of this figure may be found in the online electronic manuscript.

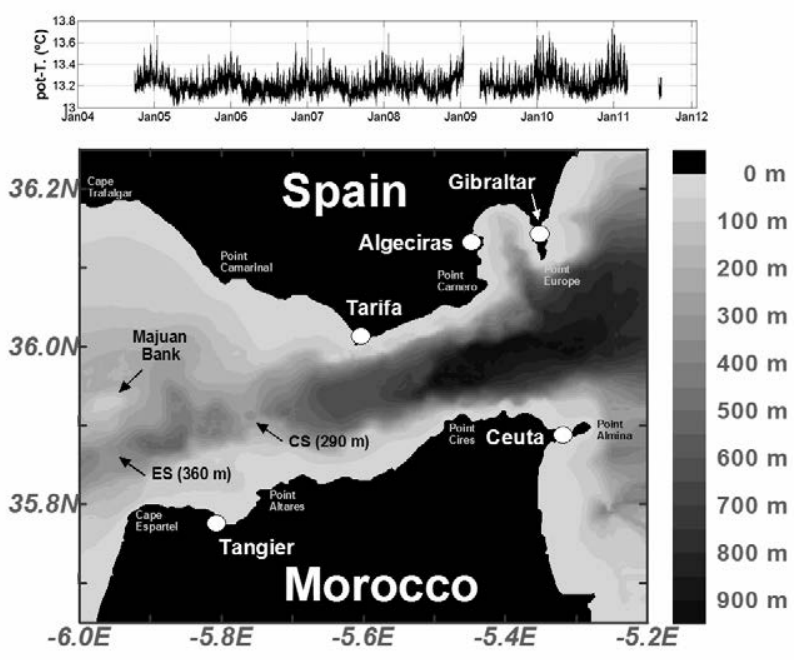

FIG. 13. - Time series of potential temperature near the sea floor $(340 \mathrm{~m})$ at the Espartel Sill mooring (west Strait of Gibraltar) from October 2004 to March 2011 (and two weeks in August 2011). The mooring was instrumented with an acoustic Doppler current profiler and temperature-salinity sensors throughout the water column. In November 2011 the mooring was moved to Espartel Sill. Source: Physical Oceanography Group at UM.

Politècnica de Catalunya, LIM-UPC, Fig. 14). Further initiatives have continued during recent years in the framework of a Spanish programme aimed at developing large singular facilities (Infraestructura Científico-Tecnica Singular, ICTS). These include the Cantabria Coastal and Ocean Basin (CCOB), with tanks and channels aimed at research in coastal hydrodynamics, the Balearic Island Coastal Observing and Forecasting System (Sistema de Observación Costera y Predicción de las Islas Baleares, 


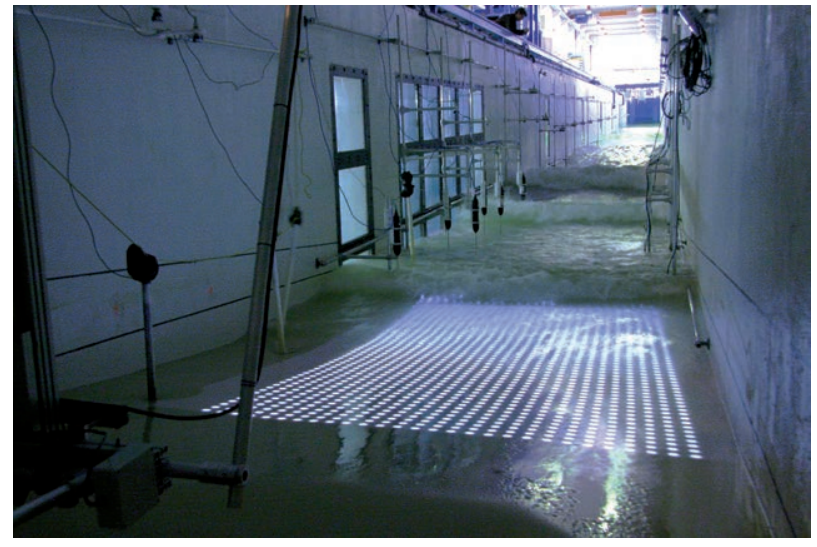

FIG. 14. - The wave flume at LIM-UPC is a European Union singular research facility. Source: LIM-UPC.

SOCIB) aimed at providing oceanographic data and modelling services to support operational oceanography, and the Oceanographic Platform of the Canary Islands (Plataforma Oceánica de Canarias, PLOCAN), aimed at creating an offshore research and technology facility.

A major contribution in the post-WOCE era has arisen through the development of a Microwave Imaging Radiometer with Aperture Synthesis (MIRAS) within the Soil

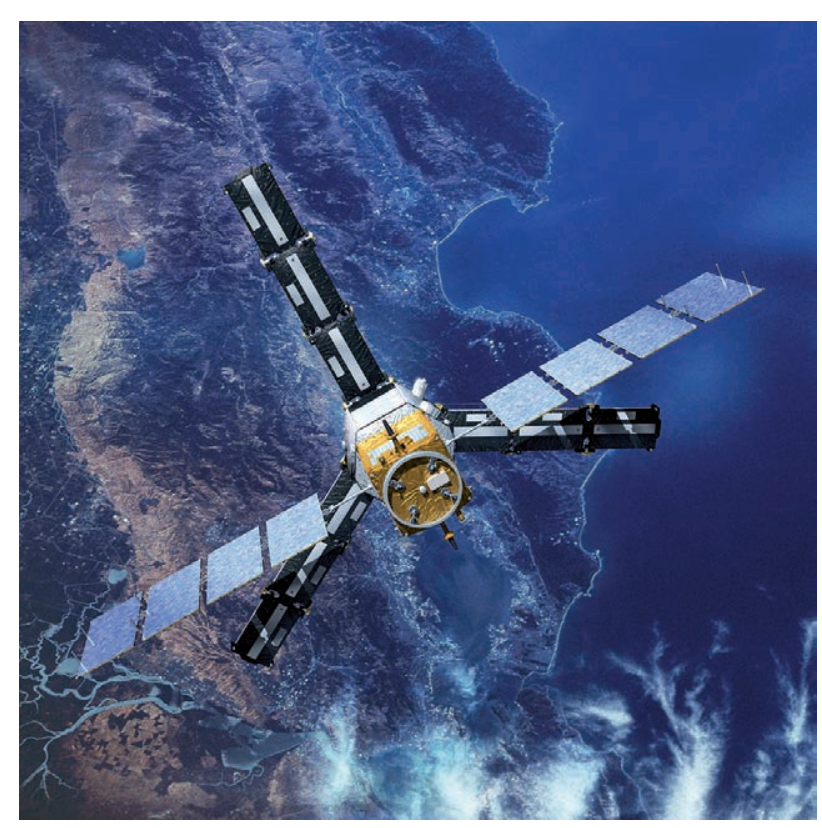

FIG. 15. - Pictorial simulation of the SMOS satellite orbiting over a coastal area, with the open solar panels and the Y-shaped arms of the interferometric microwave radiometer facing the Earth. Source: P. Carril for European Space Agency.
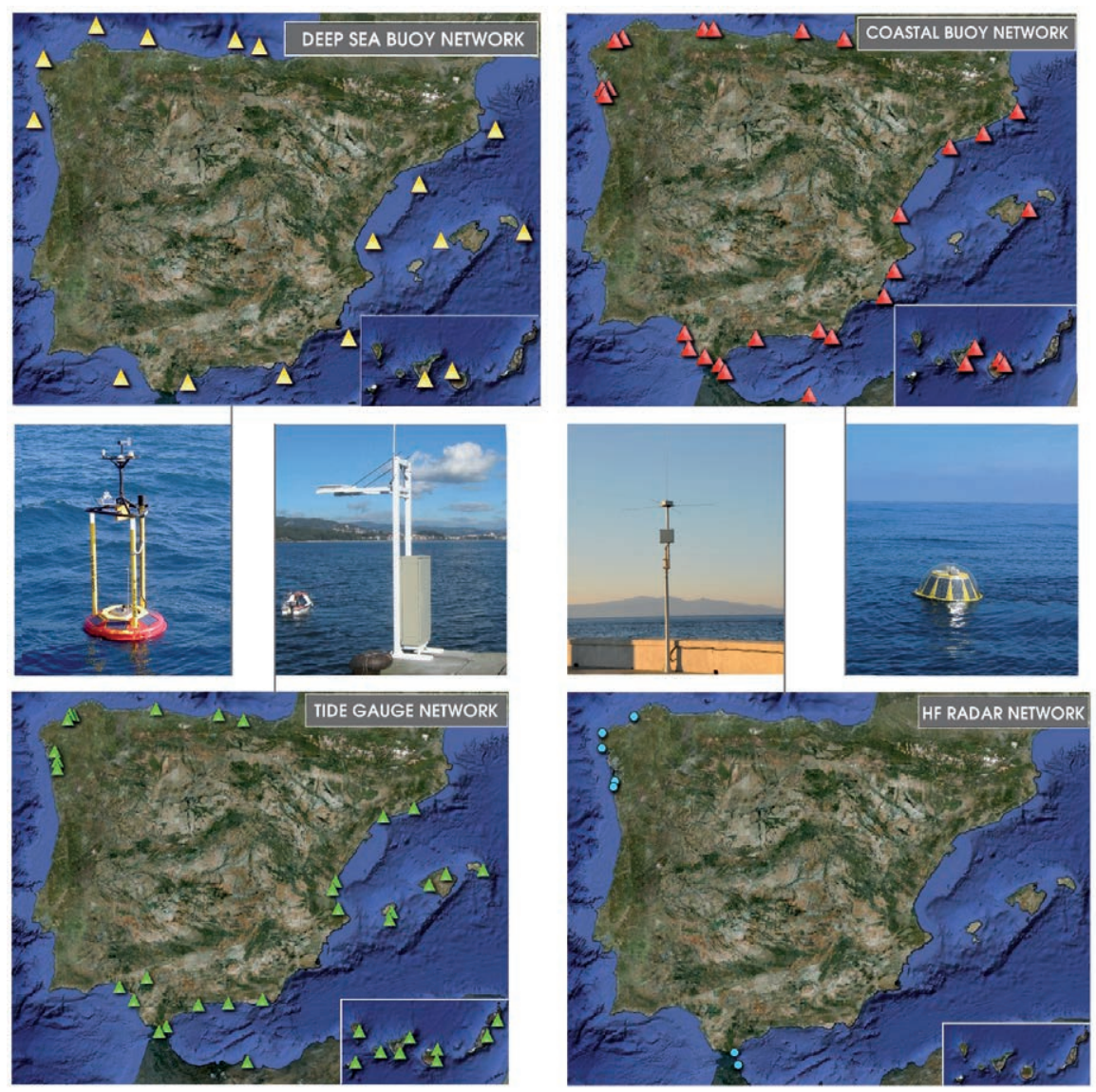

FIG. 16. - Puertos del Estado oceanographic networks. The deep-sea buoy network (Alvarez Fanjul et al. 2003) consists of multi-parametric buoys (Santander buoy is an IEO station) while the coastal buoy network consists of wave-measuring buoys, the tide-gauge network, and the high-frequency radar network (stations of INTECMAR, MeteoGalicia, UV and PdE). Source: PdE. 


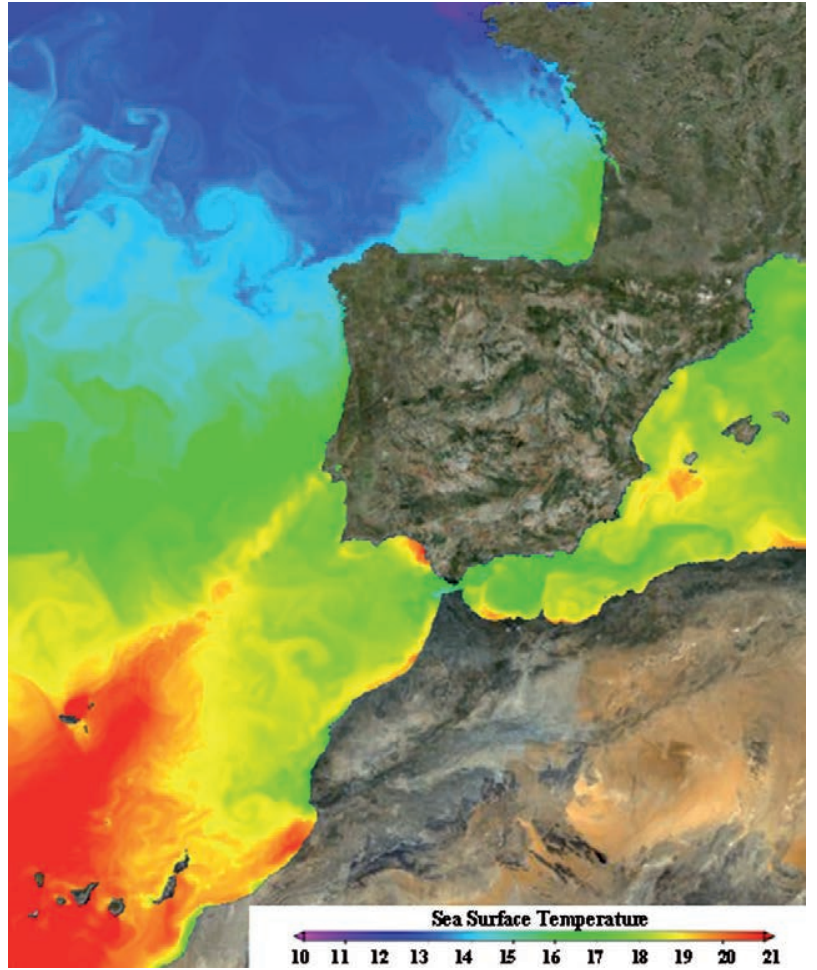

FIG. 17. - SST operational forecast for 8 May 2012 developed at MyOcean (2 km resolution), as shown daily on the PdE web page (www.puertos.es).

Moisture and Ocean Salinity (SMOS) programme of the of the European Space Agency (ESA) (Font et al. 2012) (Fig. 15). The Spanish contribution to SMOS, led by the ICM and the UPC, includes the monitoring, calibration and data retrieval of surface salinity values which are subsequently made available to the international community.

The active incorporation of university research groups has become a very important step for the definitive progression of Spanish oceanography, because of the research that they carry out and the large number of oceanographers that they train. In 1982 an undergraduate degree in marine sciences was implemented in Spain, first at the ULPGC and later at the University of Cadiz (Universidad de Cádiz, UC, in 1989), the University of Vigo (Universidad de Vigo, UV, in 1990), the University of Alicante (Universidad de Alicante, UA, in 1998) and the Catholic University of Valencia (Universidad Católica de Valencia, UCV, in 2003). The first doctoral programme in marine sciences began in 1984 as a joint programme of the UPC, the CSIC and the University of Barcelona (Universitat de Barcelona, UB). Now there are master and doctoral programmes in oceanography and coastal engineering at about a dozen Spanish universities.

From the late 1980s to today, the Spanish National Ports and Harbours Authority (Puertos del Estado, PdE) has become the main governmental body in charge of maintaining monitoring networks around the Spanish mainland and islands. The present system consists of a network of deep-ocean meteorological and oceanographic buoys, coastal and open-sea oceanographic bu- oys and tide gauges sampling at very high frequency in order to be used in a future Tsunami Warning System. In recent years, this network has been complemented with coastal high-frequency radars able to monitor surface currents in key regions such as the Strait of Gibraltar (Fig. 16). A tide-gauge network is also maintained by the IEO, in some instances with quite long time series (the oldest ones since 1943). Additionally, PdE assimilates these and other data sets to make operational predictions of sea surface conditions, including sea level, waves and currents (Fig. 17). In addition to these national networks, there are regional ones in the Cantabrian Sea maintained by the AZTI and the Cantabria government, in the Catalan Sea operated by the LIM-UPC for the Catalan government and in the Atlantic Ocean managed by the Meteorological Service of Galicia (MeteoGalicia) and
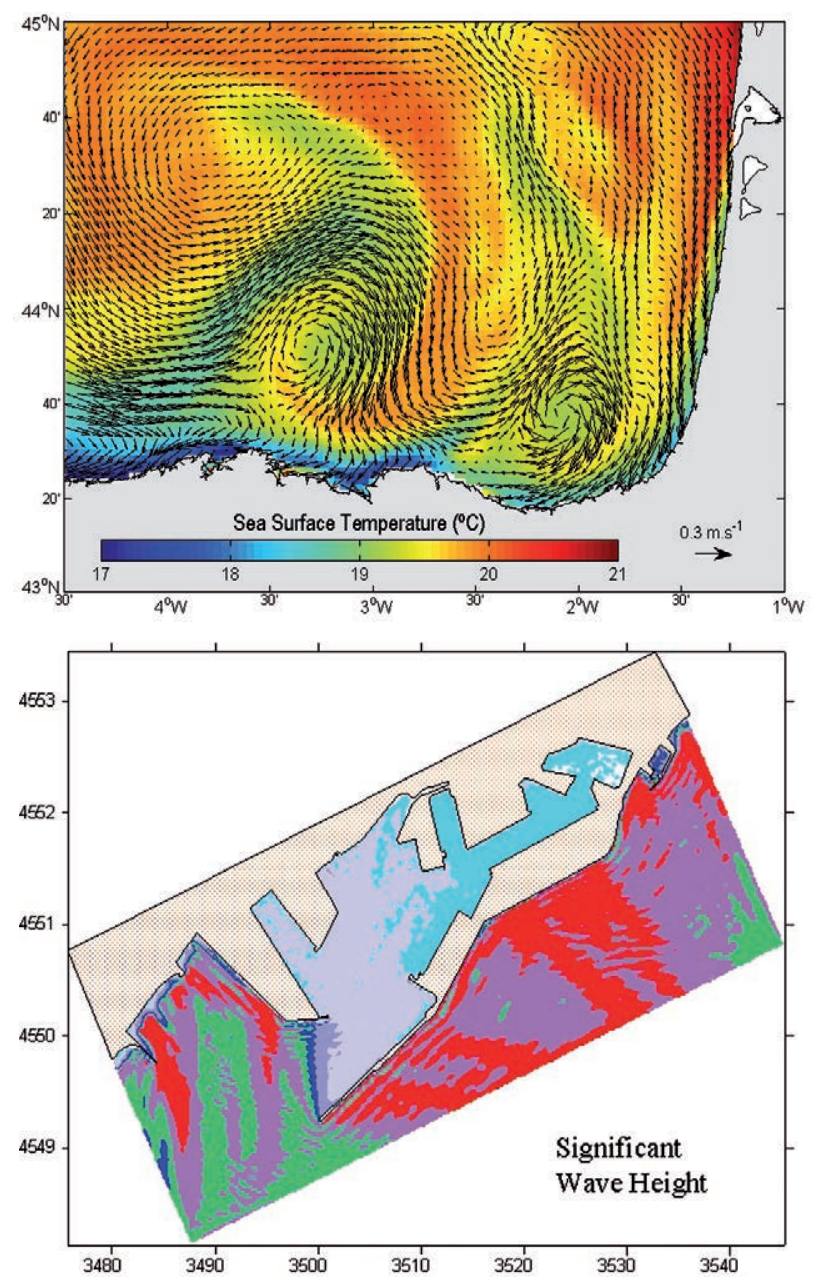

FIG. 18. - (Top) Sea surface temperature and current fields obtained with the Regional Ocean Modelling System on 18 August 2008, using six-hourly reanalysis data from the United States National Centre for Environmental Prediction as atmospheric forcing and data from the Estimating the Circulation and Climate of the Ocean project as input at the open boundaries. Source: Luis Ferrer, AZTI. (Bottom) Sample computation of significant wave height illustrating the propagation of wave trains into a Spanish Mediterranean harbour. The colour scaling indicates the wave height intensity, ranging from $0.1 \mathrm{~m}$ (light blue) to $1.0 \mathrm{~m}$ (red). Source: A. SanchezArcilla, LIM-UPC. 
the Technological Institute for the Control of the Marine Environment (Instituto Tecnológico para el Control del Medio Marino, INTECMAR) for the Galician government (Fig. 18). These national and regional bodies assimilate the data sets to make model-based operational predictions of sea level, waves and currents. In particular, all the information generated by the PdE's forecast models and monitoring systems is freely available through the internet (www.puertos.es). This service receives an average of one million hits and around 200000 single different visitors per month. This massive use is a clear demonstration of the current socio-economic importance of physical oceanography in Spain. All the data recorded by the PdE's networks, together with model hindcasts in the framework of the European HIPOCAS project, have been extensively used by the Spanish oceanographic community, and have formed the backbone of coastal and harbour engineering during the last decade.

\section{THE SPANISH PHYSICAL OCEANOGRAPHY HORIZON}

The initial worldwide growth of physical oceanography was very much based on excellence in research and educational programmes at prime institutions of countries with a long oceanographic tradition and its subsequent development has been the result of the gathering of large amounts of ocean data, which have become freely available in centralized data bases thanks to international collaboration in regional and global programmes. Spain has played a privileged role in this work, partly because of its strategic geographic location in the Mediterranean Sea and Atlantic Ocean and partly because of the contributions made by a new generation of oceanographers.

From 1989 to 1998 the European Union research framework had a specific programme on Marine Sciences and Technologies (MAST) through which Oceanography became the research field, among all European programmes, with the largest Spanish success; from 1995 to 2000, and as a consequence of this European success, a similar programme (Ciencias y Tecnologías Marinas, CYTMAR) was established within the Spanish national research programme (Duarte et al. 1999, 2006). As an example, one of the largest ever European marine science projects, CANIGO (Canary Islands, Azores and Gibraltar Observations), was led by the IEO (the principal investigator was Gregorio Parrilla) with the participation of ten Spanish research institutions (Fig. 19). In 1999 the MAST programme disappeared and European funding for marine science projects came through several thematic programmes, still with a relatively large return. Following the European inertia, in 2001 the CYTMAR Spanish programme turned into a national sub-programme (Duarte et al. 2006).

The sinking of the Prestige oil tanker off the coast of Galicia, in November 2002, marked the birth of operational oceanography in Spain. Eighteen Spanish institutions, including the Spanish Maritime Safety Agency

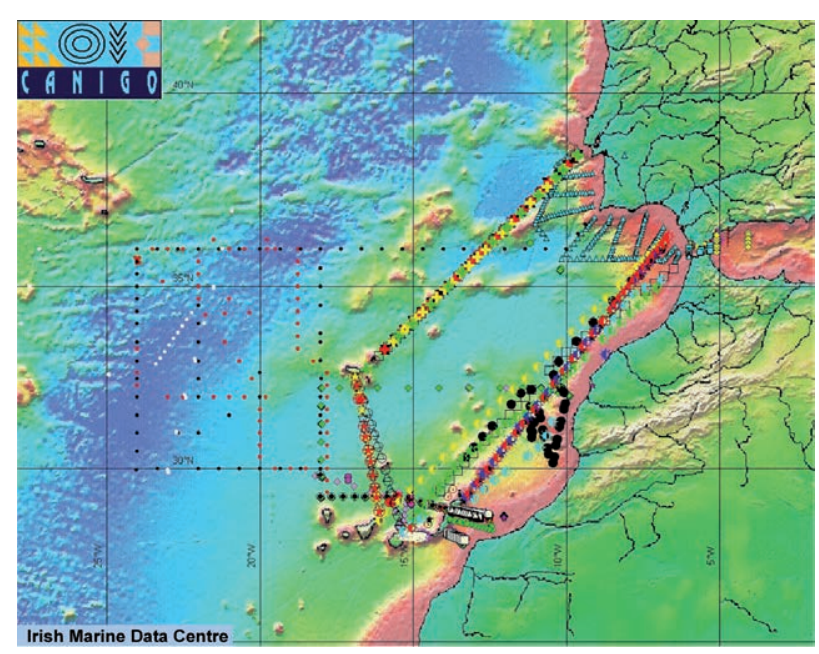

FIG. 19. - Location of oceanographic stations carried out as part of the three-year CANIGO European Union project. Source: Irish Marine Data Centre.

(Salvamento Marítimo, SASEMAR), participated in a large Spanish project with the principal objective of establishing a nation-wide operational system (Establecimiento de un Sistema Español de Oceanografía Operacional, ESEOO) capable of handling future emergencies (Fig. 20) (Álvarez Fanjul et al. 2007). ESEOO led to the creation of an inter-institutional network which today provides daily marine current forecasts to SASEMAR for use in search and rescue operations and combating oil spills, and several Spanish institutions and companies (ICM, IMEDEA, PdE, Starlab) are playing an important role in the current developments of the MyOcean and MyOcean2 projects.

The relatively large investment in marine sciences during the 1990s and 2000s was accompanied by a very substantial increase in the number of Spanish PhDs in marine sciences, particularly in physical ocea-

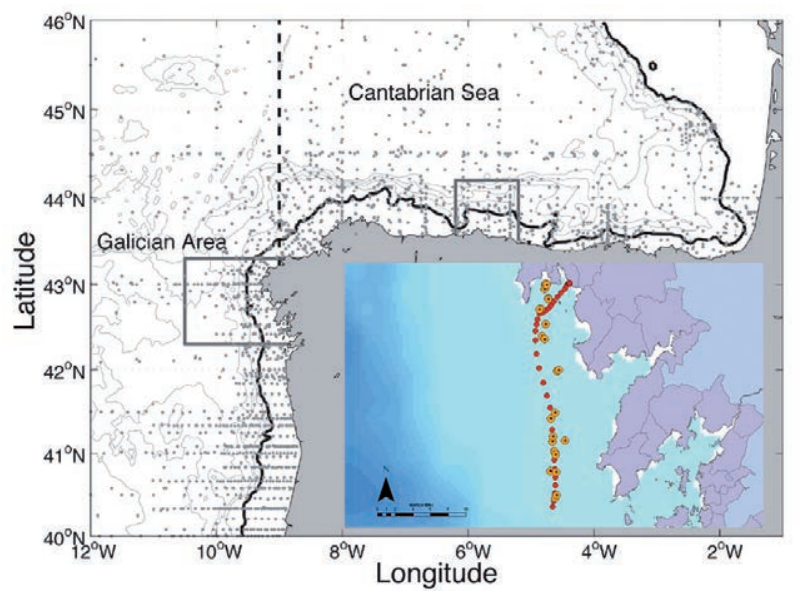

FIG. 20. - Data available in the Hydrobase dataset (gray dots) and location of the Gijon-2006 and Finisterre-2006 experiments carried out as part of ESEOO; reproduced from Machín et al. (2008). The inset shows the trajectory of actual buoys (yellow circles) and numerical buoys (red circles) launched during the Finisterre-2006 experiment. Source: Enrique Alvarez-Fanjul, PdE. A colour version of this figure may be found in the online electronic manuscript. 


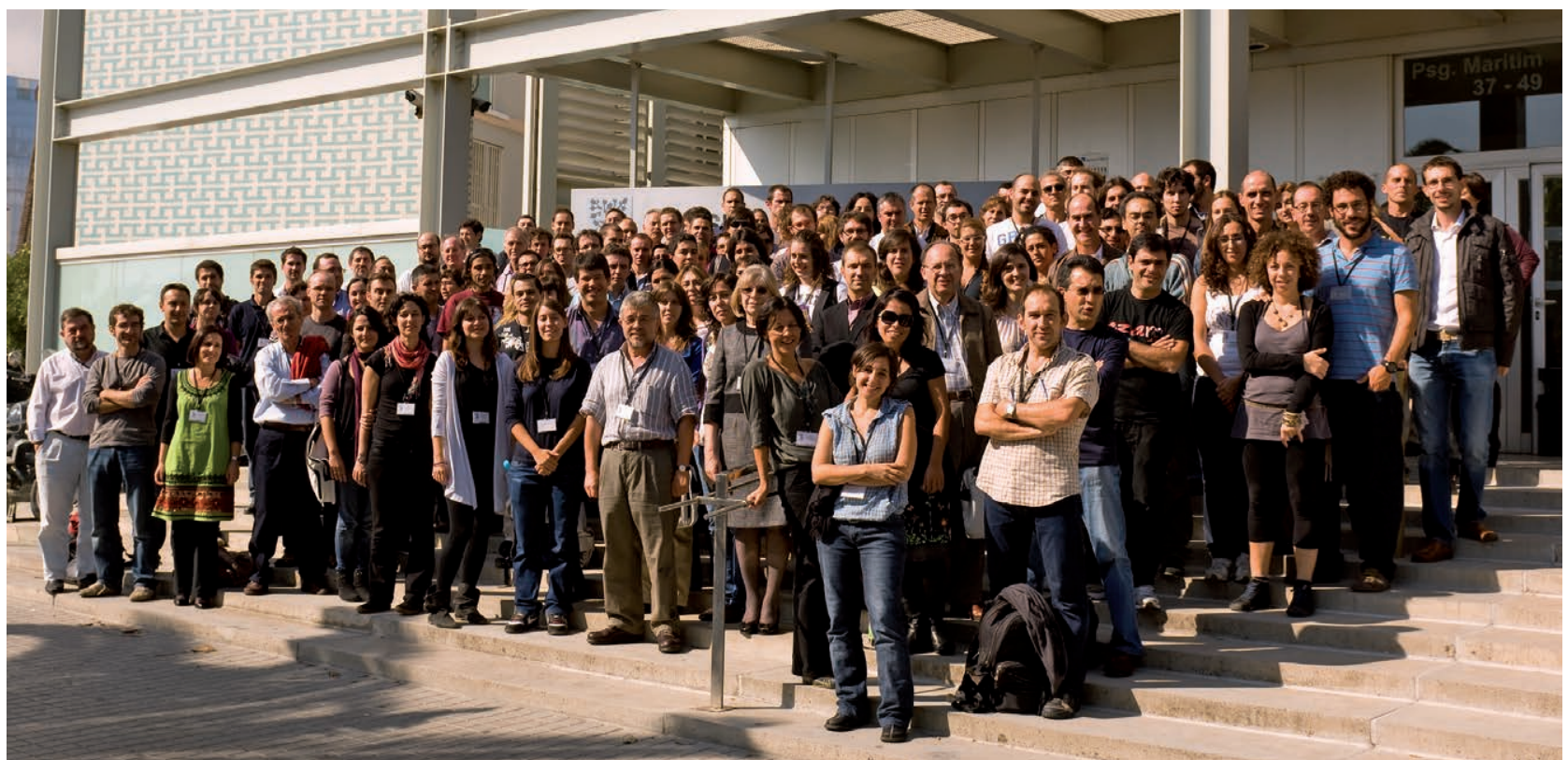

FIG. 21. - Group photo outside ICM during the EOF1 (13 to 15 October 2010). Source: Marc Gasser Rubinat, ICM.

nography. Most of the researchers came with undergraduate degrees in marine sciences, physics or civil engineering and graduated either in Spain or in other countries with a long oceanographic tradition, such as Germany, the United States, the United Kingdom, France and Belgium. A significant proportion of these young researchers had joined the Spanish system during the last ten years, either through research projects or through funding from several regional and nationwide programmes, such as the state-funded Juan de la Cierva and Ramón y Cajal programmes. Some of them have eventually become permanent additions to the Spanish research system: during the 1980s and 1990s mainly in the newly created colleges that granted degrees in marine sciences and during the 2000s mainly in governmental research (such as the IEO, the ICM, the IIM, the IMEDEA and the AZTI) and to a lesser extent in universities and private enterprises. The contribution of these very well-qualified oceanographers has marked a turning point for scientific production in marine sciences, which rose from less than 100 Science Citation Index publications in 1990 to over 800 in 2002 (Duarte et al. 2006). We may now also find young Spanish physical oceanographers working in many countries worldwide, further strengthening the Spanish international links.

While the list of research topics is very wide, according to the 1999-2007 national reports on physical oceanography (prepared by the Oceanographic Section of the Spanish Commission on Geodetics and Geophysics), the major research areas and topics have been the Gulf of Cadiz (UM, IEO and ICM), the Strait of Gibraltar and Alboran Sea (UC, UM and IEO), the Catalan-Balearic Sea (ICM, LIM-UPC and IMEDEA), the North Atlantic Ocean (IIM, ULPGC, IEO, ICCM and UV), the tropical Atlantic (ICM and UCM), the
Cantabrian Sea (AZTI and IEO), the Antarctic Ocean (IMEDEA, LIM-UPC and ULPGC), upwelling systems in boundary currents (IIM, ULPGC, UV, ICM and ICCM), the role of the ocean in climate (IEO, ICM, ULPGC, IIM and the Complutense University of Madrid [Universidad Complutense de Madrid, UCM]), coastal oceanography (LIM-UPC, the Environmental Hydraulics Institute at the University of Cantabria [Instituto de Hidráulica Ambiental de la Universidad de Cantabria, IHA-UC] and CEDEX), mixing processes (ICM, IIM, ULPGC, UV and the University of Girona [Universitat de Girona]), theoretical oceanography (ICM, the Institute for Cross-Disciplinary Physics and Complex Systems [Instituto de Física Interdisciplinar y Sistemas Complejos, IFISC] and the Institute for the Mathematical Sciences [Instituto de Ciencias Matemáticas, ICMAT]), numerical predictive modelling (PdE, LIM-UPC, UCM, ICM, UTM, ULPGC, AZTI, MeteoGalicia and IMEDEA), and marine climate characterization (PdE, IEO, IMEDEA, IHA-UC, CEDEX and the Marine Technology Centre [Centro Tecnológico del Mar, CETMAR]).

It is worth mentioning the catalysing role played by the international journal Scientia Marina in disseminating Spanish interdisciplinary research in marine sciences. The journal was founded in 1955, until 1989 under the name Investigación Pesquera. In 1998 it was included in the Science Citation Index. It publishes original papers, reviews and comments concerning all aspects of marine research, with emphasis on the interdisciplinary nature of marine sciences. The papers in this Scientia Marina special issue are just a sample of the communications presented at EOF1 (Fig. 21), illustrating some of the topics currently addressed by the Spanish physical oceanography community: Small-Scale and Coastal Processes, Mesoscale Processes, Large-Scale 
Processes, Marine Climate and Operational Oceanography, Oceans and Climate Change, and Technologies for the Marine Environment. They also exemplify the three main types of Spanish institutions that carry on research in physical oceanography: universities, research centres and governmental organizations.

Bastida et al. (2012) examine the processes leading to mixing episodes within the bottom boundary layer of a shelf area and Grifoll et al. (2012) assess the sensitivity of a forecasting system for harbours which includes the nesting of several ocean models. Peña-Izquierdo et al. (2012) use field data to give an exhaustive description of the complex current system over the continental slope off NW Africa, Mason et al. (2012) use numerical results to discuss the origin and spatio-temporal variability of the African upwelling north of the Canary Islands, and Delgado et al. (2012) use two decades of altimetry data to examine the variability and connectivity between the mesoscalar structures at both ends of the Strait of Gibraltar. Martín-Rey et al. (2012) analyse outputs from a coupled atmosphere-ocean model to show that changes in heat content in the tropical Atlantic may influence the equatorial Pacific at interannual scales and Claret $e t$ al. (2012) use novel data along the equatorial Atlantic to demonstrate convective mixing as induced by the intrusion of the highly-saline equatorial undercurrent. Jordà et al. (2012) present a new hindcast of sea surface height in the Mediterranean Sea and a sector of the NE Atlantic for the 1958-2008 period, Vidal-Vijande et al. (2012) examine the behaviour of three numerical global models against observational data in the western Mediterranean, Costa et al. (2012) validate a forecast system for the NW Iberian Peninsula based on the nesting of a Regional Ocean Modelling System to the MERCATOR ocean model for the North Atlantic, and García-Nava et al. (2012) use field data to evaluate the performance of several wind-drag parameterizations for mixed sea conditions. San Antolín et al. (2012) inspect data from three transatlantic sections along $7.5^{\circ} \mathrm{N}$ to assess how interdecadal changes in intermediate water strata may affect both stratification and double diffusion, and GarcíaOlivares and Herrero (2012) examine the sensitivity of a mechanistic glacial-interglacial model to changes in the parameters that simulate large-scale physical and chemical processes. Martín Miguez et al. (2012) compare sea level data as obtained from four different systems during several years to examine their short and long-term accuracy, Emelianov et al. (2012) propose that deep thermohaline anomalies have a signal in sea surface temperature that may be detected with a singularity analysis technique, González et al. (2012) present a conceptual design for oceanographic and meteorological offshore monitoring stations, Font et al. (2012) review the several elements of the SMOS program and provide a first validation of the operational global sea surface salinity maps, and Ruiz et al. (2012) present five years of glider activities which include studies related to glider-path planning and the integration of data from gliders and other in situ and remote platforms.

\section{FINAL CONSIDERATIONS}

The Spanish situation in the field of physical oceanography is very favourable in terms of facilities and manpower. However, the deep national economic crisis is a major threat and has led to a noticeable decrease in funding for ocean research programmes in the last year. It has also caused a dramatic reduction in the possibilities for recent graduates to join public research and educational organizations. During the following years we may expect that many Spanish oceanographers will have to leave for other countries, either temporally or permanently, in order to continue their careers. Hopefully this situation will not last very long but it is critical to design strategies and priorities for this interim period. Below we present the three main lines of action that we think should be followed in the coming years: human capital, partnership and societyoriented research.

A prime priority for the forthcoming years must be the maintenance of those programmes that ensure the training of qualified graduate students and the incorporation of specialized technicians and postgraduate researchers. It is time to maintain and improve the human capital that took so long to build up. Qualified technical, doctoral and postdoctoral positions should be opened through the national research programmes and the educational and research institutions. This is to be a priority in the strategies for investing in science during the following years and should lie well ahead of investments in new facilities. This is the only possible way to maintain and even increase the Spanish participation in European and internationally funded programmes. One outcome of this strategy would be a proper maintenance of the existing facilities and the development of our own technologies and scientific instruments.

Partnership and networking should be an underlying motive in the planning of future Spanish research projects. These projects should be coordinated in order to optimize the use of expensive facilities such as research ships, large laboratory facilities and other expensive instruments, but we must go even further. It is necessary to promote associations between researchers themselves, between institutions that carry on research and between research and society. It is also time to recover the private oceanographic associations that arose in Spain 100 years ago as the best way to reach and involve the Spanish society, from the school system to the large corporations, in the understanding and sustainable utilization of our oceans and seas. Partnerships with institutions from other countries is also to be encouraged, perhaps recovering de Buen's old idea of an Ibero-American oceanographic association. For us scientists it is also fundamental to make sure that our data are stored in databases for proper and exhaustive use, that technological developments become available to industry, and that our conclusions reach managers.

In the short or long term our research must be 
fundamentally inspired by society. Fundamental research is the backbone of growth in modern societies. Unfortunately, in the current context of crisis, this fact is sometimes not clearly perceived by the population and is therefore not endorsed by politicians. The continued development of operational oceanography, with research and state agencies playing a coordinated role, underscores the importance of oceanography for society. However, in order to promote our basic research we need to make every effort to increase the presence of our science in everyday life, advocating the downstream or added values of marine data and knowledge. This goes from boosting education at all levels to supporting the creation of private enterprises with facilities to hire technicians and researchers. The general public must become aware of the ocean's resources and their vulnerability, and of the prime importance of our oceans and seas in controlling the present and future of the Earth's climate and habitat.

\section{ACKNOWLEDGEMENTS}

The authors wish to thank the following bodies and institutions, which made the Primer Encuentro de la Oceanografía Física Española possible: the Ministerio de Ciencia e Innovación of the Spanish government, the Generalitat de Catalunya and the Consejo Superior de Investigaciones Científicas for their financial support; Obra Social Fundació La Caixa and Museu Marítim de Barcelona for their collaboration in social and cultural activities; and the Observatori Català de l'Oceà, the Institut de Ciències del Mar, the Laboratori d'Enginyeria Maritima of the Universitat Politècnica de Catalunya, and the Centre Internacional d'Investigació del Recursos Costaners for organizing the event. The authors would also like to express their gratitude to the bodies and institutions that have made possible this special issue: the Instituto Español de Oceanografía, the Observatori Català de l'Oceà, the Institut de Ciències del Mar, the Laboratori d'Enginyeria Marítima, the Universitat Politècnica de Catalunya and Puertos del Estado. Finally we would like to sincerely thank all the authors and reviewers for their support in promoting Spanish physical oceanography.

\section{REFERENCES}

Alvarez Fanjul E., Alfonso M., Ruiz M.I., López J.D., Rodríguez I. 2003. Real time monitoring of Spanish coastal waters: The deep water network. In: Dahlin H., Flemming N.C., Nittis K., Petersson S.E. (eds.), Building the European Capacity in Operational Oceanography: Proceedings $3^{\text {rd }}$ EuroGOOS Conference, Vol. 69 Elsevier Science.

Alvarez Fanjul E., Losada I., Tintoré Subirana J., Menéndez J., Espino M., Parrilla G., Martínez V.I., Muñizurri V.P. 2007. The ESEOO Project: developments and perspectives for Operational Oceanography at Spain. Proceedings of the 17th (2007) International Offshore Ocean and Polar Engineering Conference (ISOPE-2007), Lisbon, Portugal.

Arístegui J., Tett P., Hernández-Guerra A., Basterretxea G., Montero M.F., Wild K, Sangrà P., Hernández-León S., Cantón M., García-Braun J.A., Pacheco M., Barton E.D. 1997. The influence of island-generated eddies on chlorophyll distribution: a study of mesoscale variation around Gran Canaria. Deep-Sea Res. I 44: 71-96.

Barton E.D. 2009. Informe de la Campaña "CAIBEX-I" con el B/O Sarmiento de Gamboa, Cabo Sileiro, Galicia, 6-24 Julio 2009. Reporte Técnico, Subprograma Nacional de Ciencias y Tecnologías Marinas.

Bastida I., Planella J., Roget E., Guillén J., Puig P., Sánchez X. 2012. Mixing dynamics at the inner shelf of the Ebro Delta. Sci. Mar. 76S1: 31-43.

Bjerknes V., Bjerknes J., Solberg H., Bergeron Y.T. 1933. Physikalische Hydrodynamik mitdnwefidung auf diedynamische Meteorologic. Verlag Julius Springer, Berlin.

Black J., Manfredi D. 2007. A biography of Alexandro Malaspina. Malaspina University-College. http://web.viu.ca/black/amrc/ index.htm

Bode A., Lavín A., Valdés L. 2012. Cambio climático y oceanográfico en el Atlántico del norte de España. Temas de Oceanografía 5, Instituto Español de Oceanografía, 280 pp.

Bryden H.L., Kinder T.H. 1986. Gibraltar Experiment: A plan for dynamic and kinematic investigations of strait mixing, exchange and turbulence. Woods Hole Oceanogr. Inst. Tech. Rept., WHOI-86-29, 82 pp.

Claret M., Rodríguez R., Pelegrí J.L. 2012. Salinity intrusion and convective mixing in the Atlantic Equatorial Undercurrent. Sci. Mar. 76S1: 117-129.

Costa P., Gómez B., Venâncio A., Pérez E., Pérez-Muñuzuri, V. 2012. Using the Regional Ocean Modelling System (ROMS) to improve the sea surface temperature from MERCATOR Ocean System. Sci. Mar. 76S1: 165-175.

Deacon M.B. 1998. How the Science of Oceanography developed. In: Summerhayes C.P., Thorpe S.A. (eds.), Oceanography. An illustrated guide. Manson Publishing Lte., pp. 9-26.

Delgado J., García-Lafuente J., Naranjo C., Bruque E. 2012. Two decades of mesoscale phenomena on either side of the Strait Gibraltar. Sci. Mar. 76S1: 95-102.

Dickey T.D., Bidigare R.R. 2005. Interdisciplinary oceanographic observations: the wave of the future. Sci. Mar. 69 (S1): 23-42.

Donde Va Group. 1984. An oceanographic experiment in the Alboran Sea. EOS Trans. Amer. Geophys. Union 65: 682-683.

Duarte C.M., Delgado M.J., Tintoré J., Parrilla G. 1999. El programa de Ciencias y Tecnologías Marinas (MAST III). In: Delgado M.J., Duarte C.M., Tintoré J., Parrilla G. (eds.), El pulso de las Ciencias Marinas en España. Dirección General de Enseñanza Superior e Investigación Científica. Ministerio de Educación y Cultura. ISBN 84-00-07963-9. Madrid, pp. 32-45.

Duarte C.M., Acuña J.L., Álvarez Salgado X.A., Blasco D., Bordons M., Costas R., Dañobeitia J.J., Hernández León S., Losada I.J., Morales B., Nombela M.A., Ruiz J., Zanuy S. 2006. Las Ciencias y Tecnologías Marinas en España. CSIC, 292 pp.

Emelianov M., Claret M., Fraile-Nuez E., Pastor M.V., Laiz I., Salvador J., Pelegrí J.L., Turiel A. 2012. Detection of a weak meddy-like anomaly from high-resolution satellite SST maps. Sci. Mar. 76S1: 229-234.

Federal Maritime and Hydrographic Agency. 2011. The Future of Operational Oceanography: ideas, methods and products. (http:// futoore.bsh.de/) Hamburg, Germany, 25 to 27 October 2011.

Font J., Ballabrera-Poy J., Camps A., Corbella I., Duffo N., Duran I., Emelianov M., Enrique L., Fernández P., Gabarró C., González C., González V., Gourrion J., Guimbard S., Hoareau N., Julià A., Kalaroni S., Konstantinidou A., Aretxabaleta A.L., Martínez J., Miranda J., Monerris A., Montero S., Mourre B., Pablos M., Pérez F., Piles M., Portabella M., Sabia R., Salvador J., Talone M., Torres F., Turiel A., Vall-llossera M., Villarino R. 2012. A new space technology for ocean observation: the SMOS mission. Sci. Mar. 76S1: 249-259.

Fraile-Nuez E., Plaza F., Hernández-Guerra A., Vargas-Yanez M., Lavín A. 2008. Mass transport in the Bay of Biscay from an inverse box model. J. Geophys. Res. 113: C06023.

García-Nava H., Ocampo-Torres F.J., Hwang P.A. 2012. On the parametrization of the drag coefficient in mixed seas. Sci. Mar. 76S1: 177-186.

García-Olivares A., Herrero C. 2012. Fitting the last Pleistocene delta O-18 and $\mathrm{CO}_{2}$ time-series with simple box models. Sci. Mar. 76S1: 209-218.

Gomis D., García M.A., López O., Pascual A. 2002. Quasi-geostrophic 3D circulation and mass transport in the western Bransfield Strait during Austral summer 1995/96. Deep-Sea Res. II 
49: 603-621

González J., Herrera J.L., Varela R.A. 2012 A design proposal of real time monitoring stations: implementation and performance in contrasting environmental conditions. Sci. Mar. 76S1: 235-248.

Grifoll M., Jordà G., Sotillo M.G., Ferrer L., Espino M., SánchezArcilla A., Álvarez-Fanjul E. 2012. Water circulation forecasting in Spanish harbours. Sci. Mar. 76S1: 45-61.

Guerra A., Prego R. 2003. El Instituto de Investigaciones Pesqueras. Tres décadas de historia de la investigación marina española. Serie de Estudios sobre la Ciencia, 33, CSIC, 341 pp.

Guerra A., Prego R. 2011. Origen y desarrollo de la investigación marina en el CSIC. In: Puig-Samper M.A., Rebok S. (eds.), España Explora Malaspina 2010. Lunwerg, pp. 109-117.

Hempel G. 1982. The Canary Current: Studies of an Upwelling System. ICES, Rapports et Procès-verbeaux des Réunions, 180.

Hernández-Guerra A., Joyce T.M., Fraile-Nuez E., Vélez-Belchi P. 2010. Using Argo data to investigate the Meridional Overturning Circulation in the North Atlantic. Deep-Sea Res. I 57: 29-36.

IEO. 1989. El Instituto Español de Oceanografía. 75 años de investigación marina en España. Ministerio de Agricultura, Pesca y Alimentación. Secretaría Técnica, Madrid, 163 pp.

Jochum M., Murtugudde R. 2006. Physical Oceanography: Developments since 1950. Springer, $259 \mathrm{pp}$.

Jordà G., Gomis D., Álvarez-Fanjul E. 2012. The VANI2-ERA hindcast of sea level residuals: Atmospheric forcing of sea level variability in the Mediterranean Sea (1958-2008). Sci. Mar. 76S1: 133-146.

Kinder T.H., Bryden H.L. 1988. Gibraltar Experiment. Summary of the Field Program and Initial Results of the Gibraltar Experiment. Woods Hole Oceanogr. Inst. Tech. Rept., WHOI-88-30, 121 pp.

Lueck R.G., Wolk F., Yamazaki H. 2002. Oceanic velocity microstructure measurements in the $20^{\text {th }}$ century. J. Oceanogr. 58: 153-174.

Margalef R. 1971. Una campaña oceanográfica del "Coornide de Saavedra" en la región de afloramiento del noroeste africano. Inv. Pes. 35(supl.): 1-39.

Martín Míquez B., Testut L., Wöppelmann G. 2012. Performance of modern tide gauges: towards mm-level accuracy. Sci. Mar. 76S1: 221-228.

Martín-Rey M., Polo I., Rodríguez-Fonseca B., Kucharski F. 2012. Changes in the Interannual Variability of the Tropical Pacific as a response to an equatorial Atlantic forcing. Sci. Mar. 76S1: $105-116$

Mason E., Colas F., Pelegrí J.L. 2012. A Lagrangian study tracing water parcel origins in the Canary Upwelling System. Sci. Mar. 76S1: 79-94.

Munk W. 2002. The evolution of Physical Oceanography in the last hundred years. Oceanogr. 15: 135-141

Ospina-Álvarez N., Prego R., Alvarez I., deCastro M., AlvarezOssorio M.T., Pazos Y., Campos M.J., Bernardez P., GarcíaSoto C., Gómez-Gesteira M., Varela M. 2010. Oceanographical patterns during a summer upwelling-downwelling event in the Northern Galician Rias: Comparison with the whole Ria system (NW of Iberian Peninsula). Cont. Shelf Res. 30: 1362-1372.

Palanques A., García-Ladona E., Gomis D., Martín J., Marcos M., Pascual A., Puig P., Gili J.M., Emelianov M., Montserrat S., Guillén J., Tintoré J., Segura M., Jordi A., Ruis S., Basterretxea G., Font J., Blasco D., Pagès F. 2005. General patterns of circulation, sediment fluxes and ecology of the Palamós (La Fonera) submarine canyon, north western Mediterranean. Prog. Oceanogr. 66: 89-119.

Parrilla G. 1984. Meeting Report, Donde Va? Fuengirola, October, 1983, Instituto Espanol de Oceanografía.

Parrilla G., Lavín A., Bryden H., García M., Millard R. 1994. Rising temperatures in the subtropical North-Atlantic Ocean over the past 35 years. Nature 369(6475): 48-51.

Parrilla-Barrera G. 2005. Odón de Buen, forerunner of Spanish oceanography. Oceanogr. 18: 128-135.

Peña-Izquierdo J., Pelegrí J.L., Pastor M.V., Castellanos P., Emelianov M., Gasser M., Salvador J., Vázquez-Domínguez E. 2012. The continental slope current system between Cape Verde and the Canary Islands. Sci. Mar. 76S1: 65-78.

Perez F.F., Castro C.G., Álvarez-Salgado X.A., Rios A.F. 2001. Coupling between the Iberian basin - scale circulation and the
Portugal boundary current system: a chemical study. Deep-Sea Res. I 48: 1519-1533

Pérez de Rubín J. 2004. El Instituto Español de Oceanografía: sus orígenes y primeras investigaciones. IEO, $42 \mathrm{pp}$.

Pérez-Rubín Feigl J. 2011. Las ciencias marinas: sus orígenes y el desarrollo del Instituto Español de Oceanografía (1850-1985). In: Puig-Samper M.A., Rebok S. (eds.), España Explora Malaspina 2010. Lunwerg, pp. 97-108.

Pimentel J. 2011. La expedición Malaspina en el Pacífico Sur. Entre el Panóptico y la Arcadia. In: Puig-Samper M.A., Rebok S. (eds.), España Explora Malaspina 2010. Lunwerg, pp. 74-83.

Puig-Samper M.A., Rebok S. 2011. España Explora Malaspina 2010. Lunwerg, $343 \mathrm{pp}$.

Richardson P.L. 2008. On the history of meridional overturning circulation schematic diagrams. Progr. Oceanogr. 76: 466-486.

Ruiz S., Renault L., Garau B., Tintorè J. 2012. Underwater glider observations and modeling of an abrupt mixing event in the upper ocean. Geophys. Res. Lett. 39: L01603.

Ruiz S., Garau B., Martínez-Ledesma M., Casas B., Pascual A., Vizoso G., Bouffard J., Heslop E., Alvarez A., Testor P., Tintoré J. 2012. New technologies for marine research: 5 years of glider activities at IMEDEA. Sci. Mar. 76S1: 261-270.

Ruiz Cañavate A., Villanueva P., Rico J., Morales F., Arjonilla M., Villalobos J. 1986. Experimento Gibraltar, Informe de datos CTD, Octubre-Noviembre 1986. Instituto Hidrografico de la Marina, Cadiz, 86 pp.

Salat J. 1995. The interaction between the catalan and balearic currents in the southern Catalan Sea. Oceanol. Acta 18: 227-234.

Salat J., Tintoré J., Font J., Wang D.P, Vieira M. 1992. Near-inertial motion on the shelf-slope front off northeast Spain. J. Geophys. Res. 97: 7277-7281.

San Antolín Plaza M.A., Pelegrí J.L., Machín F.J., Benítez-Barrios V. 2012. Inter-decadal changes in stratification and doublediffusion in a transatlantic section along $7.5^{\circ}$ N. Sci. Mar. $76 \mathrm{~S} 1$ : 189-207.

Sánchez-Carrillo A. 2001. Los oceanógrafos españoles en el exilio: la familia De Buen y sus aportaciones a la ciencia española y mexicana. In: Sánchez Andrés A., Figueroa Zamudio S. (eds.), El exilio español y su impacto sobre el pensamiento, la ciencia y el sistema educativo mexicano. Universidad Michoacana de San Nicolás Hidalgo y Comunidad de Madrid, 40 pp. http:// dieumsnh.qfb.umich.mx/madridmexico/

Sangrà P., Gordo C., Hernández-Arencibia M., Marrero-Díaz A., Rodríguez-Santana A., Stegner A., Martínez-Marrero A., Pelegrí J.L., Pichon T. 2011. The Bransfield Current System. Deep-Sea Res. I 58: 390-402.

Stommel H. 1989. Why we are oceanographers. Oceanogr. 2: 48-54.

Sverdrup H.U., Johnson M.W., Fleming R.H. 1942. The Oceans: Their Physis, Chemistry and General Biology. Prentice-Hall, Englewood Cliffs, New Jersey.

Talley L.D., Pickard G.L., Emery W. J., Swift J.H. 2011. Descriptive Physical Ocanography: An Introduction. Sixth Edition, Elsevier.

UNESCO. 1974. The International Decade of Ocean Exploration (IDOE) 1971-1980. Intergovernmental Oceanographic Commission technical series, $13,87 \mathrm{pp}$.

Vargas Yáñez M., García Martínez M.C., Moya Ruiz F., Tel E., Parrilla G., Plaza F., Lavín A. 2007. Cambio climático en el Mediterráneo español. Temas de Oceanografía 1, Instituto Español de Oceanografía, $171 \mathrm{pp}$.

Vidal-Vijande E., Pascual A., Barnier B., Molines J.-M., Ferry N., Tintore J. 2012. Multiparametric analysis and validation in the Western Mediterranean of three global OGCM hindcasts. Sci. Mar. 76S1: 147-164.

Viudez A., Tintoré J., Haney R.L. 1996. Circulation in the Alboran Sea as determined by quasi-synoptic hydrographic observations. Part I: Three-dimensional structure gyres. J. Phys. Oceanogr. 26: 684-705.

Wangersky P.J. 2005. Methods of sampling and analysis of our concepts of ocean dynamics. Sci. Mar. 69(Suppl. 1): 75-84.

Wunsch C. 2002. How did WOCE turn out? Int. WOCE Newsletter 43: 4-9.

Received March 26, 2012. Accepted June 1, 2012.

Published online August 3, 2012. 